\title{
Sensory hair cell death and regeneration in fishes
}

\author{
Jerry D. Monroe ${ }^{1}$, Gopinath Rajadinakaran ${ }^{2}$ and Michael E. Smith ${ }^{1 *}$ \\ ${ }^{1}$ Department of Biology, Western Kentucky University, Bowling Green, KY, USA, ${ }^{2}$ Department of Genetics and Genome \\ Sciences, University of Connecticut Health Center, Farmington, CT, USA
}

Sensory hair cells are specialized mechanotransductive receptors required for hearing and vestibular function. Loss of hair cells in humans and other mammals is permanent and causes reduced hearing and balance. In the early 1980's, it was shown that hair cells continue to be added to the inner ear sensory epithelia in cartilaginous and bony fishes. Soon thereafter, hair cell regeneration was documented in the chick cochlea following acoustic trauma. Since then, research using chick and other avian models has led to great insights into hair cell death and regeneration. However, with the rise of the zebrafish as a model organism for studying disease and developmental processes, there has been an increased interest in studying sensory hair cell death and regeneration in its lateral line and inner ears. Advances derived from studies in zebrafish and other fish species include understanding the effect of ototoxins on hair cells and finding otoprotectants to mitigate ototoxin damage, the role of cellular proliferation vs. direct transdifferentiation during hair cell regeneration, and elucidating cellular pathways involved in the regeneration

OPEN ACCESS

Edited by: Francesco Moccia, University of Pavia, Italy

Reviewed by: Hernan Lopez-Schier, Helmholtz Zentrum Munchen, Germany Jonathan I. Matsui, Harvard University, USA

*Correspondence: Michael E. Smith Department of Biology, Western Kentucky University, 1906 College Heights BIvd., Bowling Green, KY 42101, USA michael.smith1@wku.edu

Received: 17 January 2015 Accepted: 21 March 2015 Published: 21 April 2015

Citation: Monroe JD, Rajadinakaran G and Smith ME (2015) Sensory hair cell death and regeneration in fishes.

Front. Cell. Neurosci. 9:131. doi: 10.3389/fncel.2015.00131 process. This review will summarize research on hair cell death and regeneration using fish models, indicate the potential strengths and weaknesses of these models, and discuss several emerging areas of future studies.

Keywords: hair cell, regeneration, ototoxicity, zebrafish, cell death, teleost, acoustic trauma, lateral line

\section{Introduction}

Hair cells are specialized mechanosensory receptors which convert external vibratory stimuli into neural signals (Hudspeth et al., 2000; Hackney and Furness, 2013). These cells are present in vertebrate auditory and vestibular organs and the lateral line system of aquatic vertebrates (Hudspeth, 1989; Corwin and Warchol, 1991; Nicolson, 2005). Hair cells can be damaged or destroyed by acoustic or chemical exposure, but non-mammalian hair cells, unlike their mammalian counterparts, can regenerate after they are damaged or lost (Corwin and Oberholtzer, 1997; Brignull et al., 2009; Rubel et al., 2013). This regenerative ability has sparked interest in studying hair cell death and restoration in fish in order to find means of promoting sensory hair cell regeneration in humans.

Ototoxic chemicals such as heavy metals, aminoglycoside antibiotics and platinum containing drugs like cisplatin that damage mammalian hair cells also target fish lateral line and inner ear hair cells (Lombarte et al., 1993; Ton and Parng, 2005; Hernández et al., 2006; Olivari et al., 2008; Giari et al., 2012; Uribe et al., 2013a). As in other vertebrates, auditory hair cells in fishes can also be damaged by intense acoustic stimuli (Smith et al., 2006; Schuck and Smith, 2009; Casper et al., 2013). Hair cell loss in fishes causes hearing and vestibular deficits (Corwin and Oberholtzer, 1997; Matsui and Ryals, 2005; Rubel et al., 2013) which can be assessed via behavioral and electrophysiological methods (Smith et al., 2006; Suli et al., 2012; Ladich and Schulz-Mirbach, 2013). 
As mammalian and fish hair cells are damaged by similar chemical and acoustic insults, many researchers are interested in studying the mechanisms of hair cell death and otoprotection in fish with the objective of developing therapeutics that may treat or prevent human hair cell loss. A majority of this research has been done in zebrafish (Danio rerio), which has become an important vertebrate model for examining embryogenesis, organ development, disease, and genetic defects (Kimmel, 1989; Driever et al., 1996; Haddon and Lewis, 1996; Zon, 1999) and is also a valuable model in hearing research. For example, the zebrafish mutants mariner and sputnik, which do not respond to vibrational stimuli, have hair cell bundle defects where the stereociliary bundles are detached from the kinocilia and are splayed (Nicolson et al., 1998). Genetic screens using zebrafish inner ear mutants have identified alteration of ear morphology, including expansion of the ear lumen, and aberrant formation and shape of the otolith (Malicki et al., 1996; Schibler and Malicki, 2007). Further, zebrafish mutants can exhibit morphological and functional defects similar to those of mouse mutants (Ernest et al., 2000). Considerable genetic and organ system homology exists between zebrafish and humans (Barbazuk et al., 2000; Goldsmith and Jobin, 2012). Many of the genes expressed in the embryonic zebrafish inner ear during the onset of hair cell differentiation and innervation are also expressed in other vertebrates (Coimbra et al., 2002). These include members of the Notch signaling pathway which regulate sensory cell commitment in mammalian models as well as numerous other orthologs with human genes. Thus, zebrafish models can provide insight into human hearing diseases and their mechanisms and have some advantages over mammalian models (Table 1).

Both hair cell damage and regeneration research in fishes have primarily focused on the lateral line because of its accessibility and visibility, which greatly facilitates the study of cellular and molecular mechanisms of development and differentiation (Brignull et al., 2009; Groves, 2010; Esterberg et al., 2013; Lush and Piotrowski, 2014a; Thomas et al., 2015a), although, recent efforts have begun to characterize these processes in the teleost inner ear as well (Schuck and Smith, 2009; Millimaki et al., 2010; Tanimoto et al., 2011). Researchers are also beginning to elucidate the genetic and molecular signaling mechanisms that regulate fish auditory sensory hair cell loss and restoration (Brignull et al., 2009; Ma and Raible, 2009; Schuck et al., 2011; Namdaran et al., 2012). This article reviews the current knowledge regarding hair cell death and regeneration in fishes, the advantages and disadvantages of using fish in these studies, and concludes by suggesting several future avenues for study.

\section{Anatomy and Physiology of Teleost Hair Cells}

\section{The Teleost Lateral Line}

The fish lateral line contains hair cells in sensory patches known as neuromasts (Figures 1A-D). These patches are arrayed either on the surface (superficial neuromasts) or in a fluid-filled channel with pores connecting to the outside (canal neuromasts) (Coombs et al., 2001; McHenry and van Netten, 2007). Neuromasts ultimately develop 15-20 hair cells surrounded by two accessory cell types, supporting and mantle cells (Villegas et al., 2012). They are classified as being either part of the anterior lateral line (ALL), which are located on the head, or the posterior lateral line (PLL), which are found along the trunk and tail (Ghysen and Dambly-Chaudière, 2004). Lateral line hair cells detect hydrodynamic pressure variations providing crucial sensory information required for fundamental behaviors including rheotaxis, schooling, prey detection, and predator avoidance (Coombs et al., 2001; Liao, 2006; Suli et al., 2012). Neuromast cellular layers and nervous connections are similar to those of the inner ear sensory macula (Nicolson, 2005; Haehnel et al., 2012). However, the ciliary bundles of lateral line hair cells project into a gelatinous compartment, the cupula, where vibrational forces are transduced by the gel's motion against the ciliary bundles (Nicolson, 2005; McHenry and van Netten, 2007). Morphological observations show that newly differentiating or functionally immature hair cells mainly originate from the edge of the neuromast and migrate toward the center (Williams and Holder, 2000; López-Schier and Hudspeth, 2006; Kindt et al., 2012).

Most of what is known about hair cell death, regeneration and ototoxicity in fishes come from studies of zebrafish lateral line neuromasts (Williams and Holder, 2000; Harris et al., 2003; Hernández et al., 2006; López-Schier and Hudspeth, 2006; Ma et al., 2008). While the lateral line system has led to some remarkable discoveries, it has some potential weaknesses. First, the physical arrangement of neuromast hair cells and supporting cells is quite different from the auditory sensory epithelia in vertebrate inner ears. Secondly, most of the zebrafish lateral line studies are done within the first 5 days following fertilization. Thus, it is unclear whether the observed effects are influenced by developmental plasticity or distinct hair cell death and regenerative pathways. For these reasons, researchers are beginning to perform these studies in the inner ear of adult fishes (Smith et al., 2006; Schuck and Smith, 2009; Uribe et al., 2013b).

\section{The Teleost Inner Ear}

Unlike mammals, fishes have no external or middle ears. Instead, they possess two inner ears located adjacent to the brain enclosed in a pair of capsules in the cranium. The auditory system of teleost fishes consists of three sensory otolithic end organs, the saccule, lagena and utricle (Bever and Fekete, 2002; Nicolson, 2005; Inoue et al., 2013; Figures 1E,F). These end organ compartments are filled with endolymphatic fluid and are interconnected by vestibular semicircular canals (Nicolson, 2005; Cruz et al., 2009). In many ostariophysan fish, like zebrafish, these fluid-filled compartments are attached at their posterior end to a set of four small bones, the Weberian ossicles, which are interconnected by ligaments, and form a connection to the air-filled swim bladder (Bang et al., 2001). The Weberian ossicles function as an accessory hearing structure to transmit sound vibrations from the swim bladder to the inner ear sensory end organs. Fishes do not have a dedicated 
TABLE 1 | Comparison of some advantages and disadvantages of zebrafish and rodent models of sensory hair cell death and regeneration.

Zebrafish

Low husbandry cost/space per animal

Large \# of synchronous developing embryos per mating

Embryos and larvae translucent for ex utero visualization

Easier access of sensory hair cells

Hearing range lower frequency than humans

Large-scale mutagenesis

High-throughput genetic/drug screening

In vivo model using neuromast hair cells

Transgenic models available

$70 \%$ homology with human genome*
Rodent

Higher husbandry cost/space per animal

Production of 3-14 pups/litter

Embryos opaque and in utero

Hair cells embedded in bony capsule

Hearing range comparable to humans

Several years to develop knockout mice

Lower-throughput genetic/drug screening

Inner ear must be dissected out

Transgenic models available

$90 \%$ homology with human genome*

+/- Relative advantage/disadvantage. *Percentages are approximations.

auditory organ like the mammalian cochlea, and while the otolithic organs have both vestibular and auditory functions it is generally thought that the utricle is primarily a vestibular organ, the saccule is thought to be primarily responsible for sound detection in most fish species, and the lagena supplements the functions of the saccule with roles in both orientation and hearing (Popper et al., 2003; Kwak et al., 2006; Khorevin, 2008). These pouch-like organs contain an area lined with sensory epithelia, referred to as a macula. The macula consists of a basal lamina which underlies a layer of non-sensory supporting cells with interspersed hair cells (Oesterle and Stone, 2008; Inoue et al., 2013). Neurons extend between the supporting cells forming synaptic connections with hair cells (Szabo et al., 2007; Tanimoto et al., 2009). Ciliary bundles consisting of one kinocilium and multiple stereocilia project from the hair cell body into the lumen where they contact an otolith, a

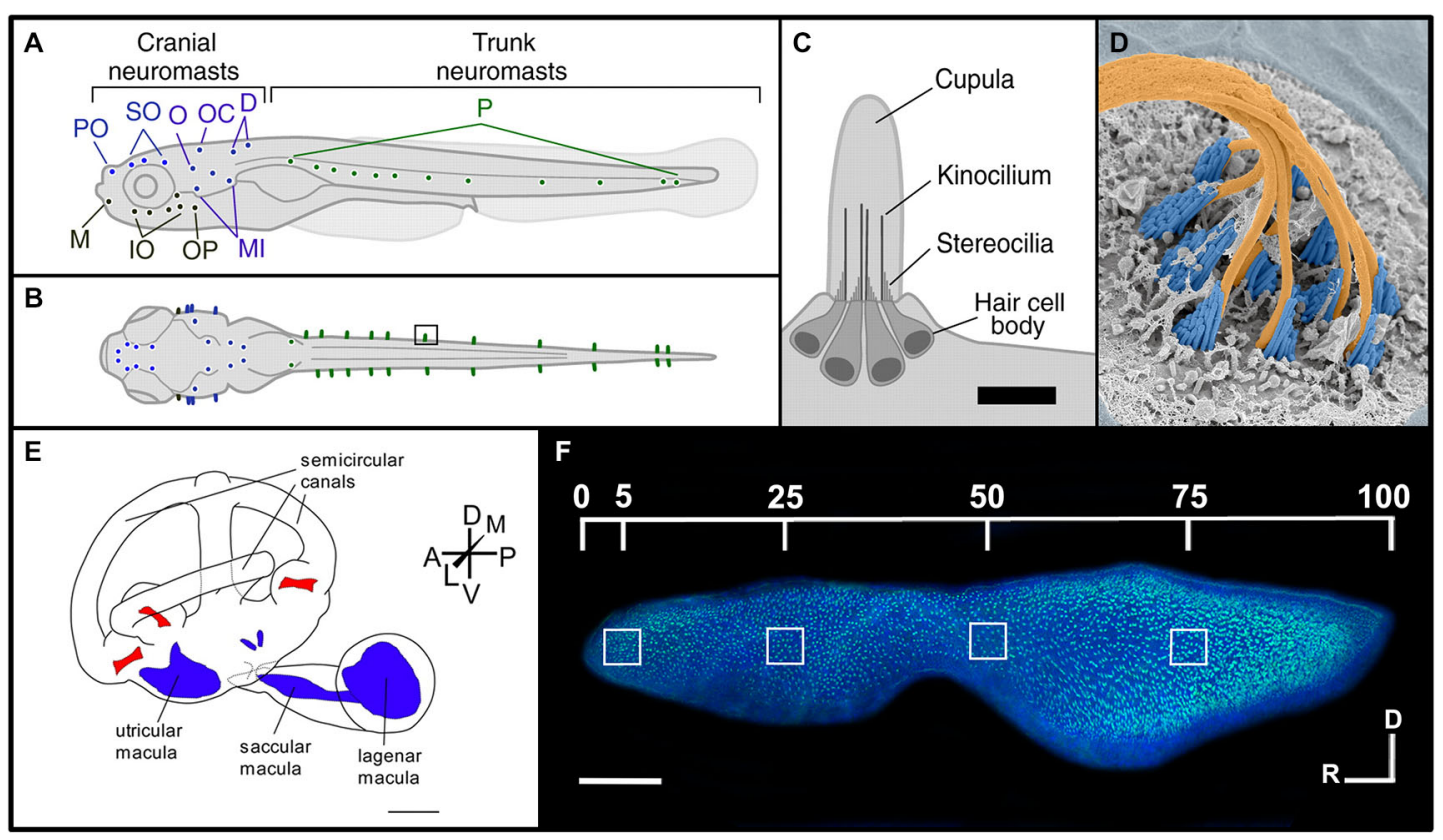

FIGURE 1 | Morphology of the lateral line and inner ear systems of zebrafish. (A) Lateral and (B) dorsal views of zebrafish larvae illustrate the distribution of neuromasts along the body. The supraorbital region (blue) includes the preoptic (PO) and supraorbital (SO) neuromasts. The infraorbital region (black) includes the mandibular $(\mathrm{M})$, infraorbital $(\mathrm{IO})$ and opercular $(\mathrm{OP})$ neuromasts. The caudal-cranial region (purple) includes the otic $(\mathrm{O})$, occipital $(\mathrm{OC})$, dorsal $(\mathrm{D})$ and middle $(\mathrm{Ml})$ neuromasts. Finally, the posterior $(\mathrm{P})$ neuromasts are located in the trunk region (green). (C) The morphology of an individual neuromast illustrates its major anatomical features. Scale bar, $10 \mu \mathrm{m}$. Reproduced with permission from Van Trump and McHenry (2008)

(D) False-colored SEM image of a zebrafish neuromast. The cupula has been removed to see the kinocilia (orange) and the stereocilia (blue). Reprinted from cover image of Developmental Cell, Vol. 23, (2), K.S. Kindt, G. Finch, T. Nicolson, Kinocilia mediate mechanosensitivity in developing zebrafish hair cells, 2012, with permission from Elsevier. (E) Morphology of the zebrafish inner ear, showing the relative positions of the sensory maculae (blue) and cristae (red). Scale bar, $500 \mu \mathrm{m}$. Adapted with permission from Hammond et al. (2010). (F) Phalloidin- and DAPI-labeled zebrafish saccule, showing locations used for quantifying hair cell bundle densities along the rostral-caudal axis. Scale bar, $100 \mu \mathrm{m}$. Reprinted from Hearing Research, Vol. 253, J.B. Schuck, M.E. Smith, Cell proliferation follows acoustically-induced hair cell bundle loss in the zebrafish saccule, 2009, with permission from Elsevier. 
calcium carbonate structure found inside the lumen of each end organ (Bever and Fekete, 2002; Nicolson, 2005; Cruz et al., 2009; Inoue et al., 2013). Stereocilia are connected by elastic tip links and when deflected by the denser otolith, transduce either excitatory or inhibitory stimuli depending upon their directional movement (Nicolson, 2005). Newly formed hair cells may arise throughout the teleost inner ear maculae (Popper and Hoxter, 1990; Lombarte and Popper, 1994; Higgs et al., 2001).

\section{Similarities and Differences Between Teleost and Mammalian Hair Cells}

Since fishes are the common ancestor of all tetrapods (Clack, 2012), it is not surprising that teleost and mammalian hair cells share many fundamental features (Coffin et al., 2004). All sensory hair cells are elongate epithelial cells. On their apical surface there is a ciliary bundle composed of multiple actinrich stereocilia and a single, eccentrically-placed kinocilium (a true cilium with $9+2$ microtubule pattern; Popper, 1983). The stereocilia are graded in size, with the longest ones lying closest to the kinocilium, and shorter stereocilia positioned in rows in steplike positions away from the kinocilium. Filamentous tip links connect each stereocilia to its nearest neighbor (Pickles et al., 1988). These tip links are composed of two cadherin molecules- protocadherin 15 (PCDH15) and cadherin 23 (CDH23; Siemens et al., 2004; Ahmed et al., 2006), but it is likely that other proteins are also involved. It is hypothesized that the tip links interact with myosin motors that move along actin filaments in the stereocilia (Howard and Hudspeth, 1987; Holt and Corey, 2000; Furness et al., 2010).

Mechanotransduction occurs when hair cell stereociliary bundles are deflected toward the kinocilium, stretching the tip links, opening cation-selective channels, and thus depolarizing the cell, while deflection away from the kinocilium hyperpolarizes the cell (reviewed in Strassmaier and Gillespie, 2002). The precise structure of the mechanotransductive channel is currently not known but may incorporate transmembrane channel-like (TMC) 1 and 2 and TMIE proteins (Pan et al., 2013; Zhao et al., 2014). As this research has only been done using mammalian hair cells, there is no data available on the mechanotransduction channel structures in fishes.

There are obvious morphological differences between the hair cells of the inner ear and lateral line of teleosts and those of the mammalian cochlea. For example, cochlear hair cells are arranged in precise rows while the hair cells of teleost maculae are found as patches of fairly equally-spaced hair cells surrounded by supporting cells, similar to those of the mammalian utricle and saccule (Corwin and Warchol, 1991). Also, while auditory, vestibular, and lateral line teleost hair bundles are generally conical in shape with a kinocilium and many rows of stereocilia, mammalian cochlear hair bundles lose the kinocilium upon maturation and have stereocilia organized in fewer rows (3-4) arranged in a more or less pronounced $\mathrm{W}$-shape (reviewed in Furness and Hackney, 2006).

Another morphological difference between teleost and mammalian hair cells that may represent a structural barrier to hair cell regeneration in mammals is cytoskeletal organization. A comparative study of six vertebrates, including zebrafish and dogfish sharks, showed that mammalian supporting cells have very large circumferential F-actin belts and intercellular junctions that express E-cadherin (Burns et al., 2013). However, supporting cells in zebrafish and adult sharks have thin F-actin belts and zebrafish have little E-cadherin. This suggests that fish supporting cells are able to divide and form new hair cells at least partially due to their unique cytoskeletal and cell adhesion characteristics.

Teleost hair cells exhibit considerable heterogeneity, but there are two basic types: Type I-like and Type II hair cells. Type I-like hair cells are located near the macular striola and have both afferent and efferent innervation (Popper, 2000). They are characterized by large, subnuclear bodies of endoplasmic reticulum, large mitochondria, and smaller synaptic bodies associated with synapses (Chang et al., 1992). Type II hair cells are extrastriolar with mostly afferent innervation. Studies suggest that the lateral line canal neuromasts are probably Type I-like cells and free neuromasts may be Type II hair cells (Song et al., 1995), although these identifications have been questioned (Van Trump et al., 2010; Brown et al., 2011). The mammalian cochlea also has two distinct hair cell types. There are inner hair cells (IHCs), the primary auditory receptors, which send afferent signals to the auditory processing centers of the brain, and outer hair cells (OHCs), which receive efferent signals from the brain and act as a cochlear amplifier which sharpens the frequency tuning curves along the length of the cochlea (Vater et al., 2004). It is thought that IHCs and OHCs are homologous to Type I-like and Type II hair cells, respectively. Mammalian vestibular Type I hair cells are amphora or cylindrically shaped but with a constricted neck and Type II hair cells are cylindrically shaped (Kevetter and Correia, 1996). A large nerve calyx surrounds the mammalian IHC hair cell, while this is usually not found in teleost hair cells (Popper, 2000).

Recently, whole-cell patch clamp analysis of zebrafish hair cells has allowed comparison of the physiological properties between hair cells from different locations (lateral line vs. inner ear) and with mammals (Olt et al., 2014). This study showed that all zebrafish hair cells exhibit a delayed rectifier $\mathrm{K}^{+}$current, but mature lateral line hair cells located in the center of neuromasts have large A-type $\mathrm{K}^{+}$currents $\left(I_{\mathrm{A}}\right)$ while immature hair cells at the neuromast edge expressed a large conductance $\mathrm{Ca}^{2+}$ activated $\mathrm{K}^{+}$current $\left(I_{\mathrm{K}, \mathrm{Ca}}\right)$ and a small $I_{\mathrm{A}}$. Further, mature zebrafish hair cells physiologically resembled those of other lower vertebrates, and to some extent, the hair cells from immature mammalian vestibular and auditory systems (Olt et al., 2014). However, it is not certain whether zebrafish hair cell physiology resembles that of clinically relevant mature mammalian hair cells.

\section{Causes and Mechanisms of Hair Cell Damage}

\section{Ototoxins}

Fish inner ear and lateral line hair cells may be damaged by many of the same ototoxic chemicals that cause impaired auditory 
and vestibular function in mammals. These substances include heavy metals, platinum-based drugs, aminoglycoside antibiotics and alkaloids (Yan et al., 1991; Lombarte et al., 1993; Song et al., 1995; Harris et al., 2003; Ton and Parng, 2005; Hernández et al., 2006, 2007; Santos et al., 2006; Chiu et al., 2008; Ma et al., 2008; Olivari et al., 2008; Van Trump et al., 2010; Buck et al., 2012). Fish species tested with ototoxins include goldfish (Carassius auratus, Ramcharitar and Brack, 2010), Atlantic cod (Gadus morhua, Faucher et al., 2009), Mexican blind cavefish (Astyanax mexicanus, Van Trump et al., 2010), oscar (Astronotus ocellatus, Lombarte et al., 1993; Song et al., 1995), and zebrafish (Danio rerio, Hernández et al., 2006, 2007; Santos et al., 2006; Olivari et al., 2008; Van Trump et al., 2010; Uribe et al., 2013a). Ototoxic exposure of the lateral line can be accomplished by dissolving chemicals in the growth media of fish larvae (Harris et al., 2003; Ton and Parng, 2005; Hernández et al., 2006, 2007; Santos et al., 2006; Ma et al., 2008; Olivari et al., 2008; Van Trump et al., 2010), while exposure of the inner ear can be done via systemic or inner ear injection (Yan et al., 1991; Lombarte et al., 1993; Faucher et al., 2009; Uribe et al., 2013b). The degree of hair cell damage depends on ototoxin concentration (Yan et al., 1991; Ton and Parng, 2005; Hernández et al., 2006; Olivari et al., 2008) and exposure time (Song et al., 1995).
One heavy metal that is ototoxic to fish hair cells is copper. Treatment with $1 \mu \mathrm{M}$ copper sulfate for $2 \mathrm{~h}$ did not cause morphological damage to larval zebrafish neuromasts, but hair cells were completely damaged at $50 \mu \mathrm{M}$ (Hernández et al., 2006). Copper can also damage supporting cells. At $10 \mu \mathrm{M}$ exposure, mantle and interneuromastic cells are moderately damaged, while at $50 \mu \mathrm{M}$, mantle, but not interneuromastic cells, are completely destroyed (Hernández et al., 2007). Mammalian studies have shown that copper transporters and pumps are responsible for cisplatin influx, sequestration and efflux (Ding et al., 2011). However, copper sulfate, an inhibitor of the copper transporter, CTR1, which modulates cisplatin influx in rodent models, can cause ototoxicity or otoprotection against cisplatin depending on dosage (More et al., 2010; Ding et al., 2011). In fact, CTR1 mRNA is expressed in zebrafish lateral line hair cells (McDermott et al., 2007), although, the level of CTR1 protein expression and its functionality has not yet been studied in either zebrafish lateral line or inner ear hair cells. Further, mRNA tissue expression of copper transporter genes can vary significantly between mammals, zebrafish and other fish species after copper exposure (Leung et al., 2014). Therefore, mammalian hair cells may respond differently than fish to copper-based compounds.

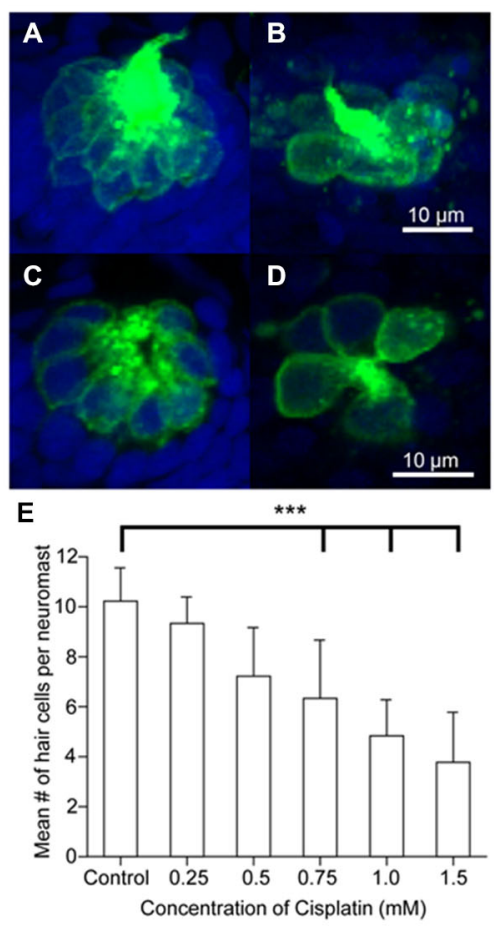

FIGURE 2 | Dose response curves following cisplatin and DMSO treatment. Brn3c-green fluorescent protein (GFP) transgenic zebrafish were exposed to varying doses of cisplatin for $4 \mathrm{~h}$, then fixed and co-labeled with TO-PRO-3 (blue), and the GFP-tagged hair cells (green). Neuromasts were imaged using confocal microscopy. (A,B) Z-stack projections of two neuromasts under different treatment conditions showing the entire neuromast structure. (C,D) Slices from the same neuromasts as in A, B demonstrating the

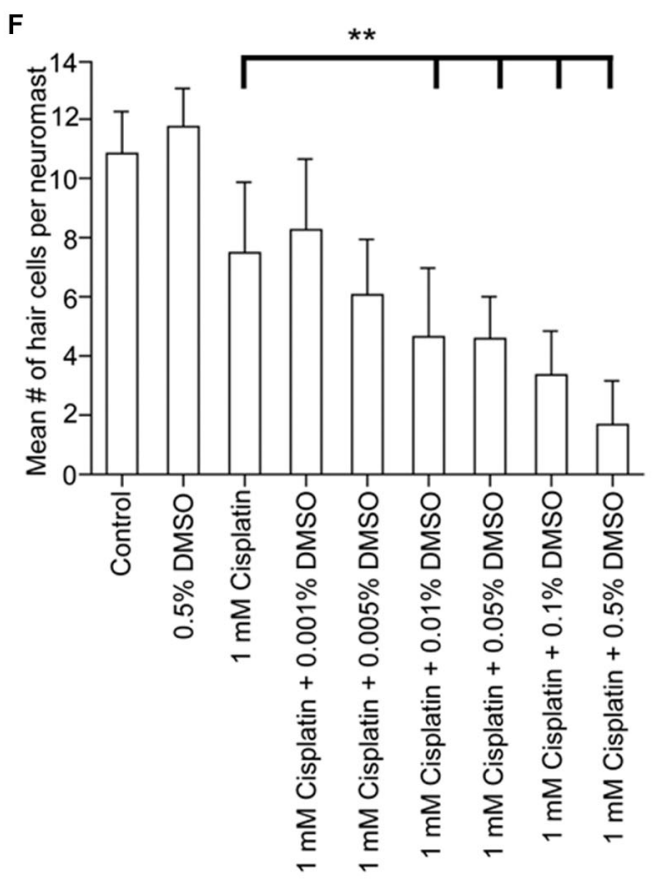

membrane-bound GFP label surrounding the nuclear dye. Neuromasts of untreated controls $(\mathbf{A}, \mathbf{C})$ and $1 \mathrm{mM}$ cisplatin-treated fish (B,D). (E) Dose-response curve for the effect of cisplatin on neuromast hair cell number. ${ }^{\star \star \star} p<0.001$ when individual treatments are compared to untreated controls. (F) Dose-response curve showing the synergistic effects of cisplatin and DMSO on neuromast hair cell number. ${ }^{* *} p<0.01$ when individual treatments are compared to untreated controls (modified from Uribe et al., 2013a). 
Zebrafish hair cells can also be damaged by the anticancer platinum-based compound, cisplatin, which is also ototoxic in mammals (Ton and Parng, 2005; Ou et al., 2007; Chiu et al., 2008; Owens et al., 2008; Giari et al., 2012). Transmission and scanning electron microscopy shows that cisplatin damages inner ear more than lateral line hair cells with greater numbers of damaged mitochondria in the inner ear cells than in the lateral line (Giari et al., 2012). The mechanism responsible for increased inner ear sensitivity is not known, although lateral line hair cells require mechanotransduction for cisplatin influx (Thomas et al., 2013). However, rodent studies suggest that cisplatin uptake in mammals may depend upon membranous transporters (Ciarimboli et al., 2010; More et al., 2010; Ding et al., 2011; Ciarimboli, 2012). It is unknown whether cisplatin uptake in zebrafish inner ear hair cells is mechanotransduction or transporter dependent. Cisplatin-mediated hair cell damage may be modulated by other chemicals. For example, ototoxicity increases in zebrafish lateral line hair cells treated with cisplatin when they are also exposed to the pharmaceutical solvent, DMSO, although DMSO treatment alone does not cause hair cell death (Uribe et al., 2013a; Figure 2). Cisplatin and other anti-cancer drugs can produce synergistic ototoxic effects in the zebrafish lateral line (Hirose et al., 2011). Experiments investigating DMSO and synergistic effects have not been performed in zebrafish inner ear hair cells, however, in rats, DMSO can cause hair cell death by activating apoptotic pathways (Qi et al., 2008). Studies in guinea pigs have also found that DMSO has an otoprotective effect which can be enhanced by co-application of a synergistic agent (Momin et al., 2011). These results suggest that platinum-based compounds and synergistic agents may cause different ototoxic effects in mammalian vs. zebrafish hair cell models.

Aminoglycoside antibiotics that are ototoxic in mammals can also cause hair cell death in fish (Ton and Parng, 2005; Chiu et al., 2008). For example, gentamicin and neomycin cause ototoxicity in the zebrafish lateral line (Ton and Parng, 2005), and streptomycin damages the superficial and canal neuromasts of goldfish (Higgs and Radford, 2013). Although different levels of gentamicin-induced damage in superficial vs. canal neuromasts have been reported (Song et al., 1995), another study showed that zebrafish superficial and canal neuromasts were damaged to a similar extent when exposed to gentamicin (Van Trump et al., 2010). Therefore, results obtained with aminoglycosides may be species specific and warrant careful consideration regarding choice of a particular fish model. Zebrafish inner ear studies show that gentamicin injection also damages hair cells in the saccular and utricular sensory epithelium and causes auditory functional deficits (Uribe et al., 2013b).

Rodent models of aminoglycoside ototoxicity can present disadvantages. Induction of aminoglycoside-mediated ototoxicity in mice often requires drug treatments that cause significant mortality and complex delivery methods (MurilloCuesta et al., 2010). Furthermore, gentamicin studies in guinea pigs demonstrate that this drug is more vestibulotoxic than ototoxic (Zhai et al., 2010). Aminoglycoside studies in mice have also exhibited distributed hair cell damage patterns where outer hair cells are mostly destroyed but many inner hair cells are left intact (Taylor et al., 2008). Thus, the ototoxic effects of aminoglycosides on fish models may be different than that of their mammalian counterparts.

Developmental factors may play a significant and complicating role in zebrafish models of aminoglycoside ototoxicity. For example, in larval lateral line studies, hair cell susceptibility to neomycin increases during later stages of development (Murakami et al., 2003; Santos et al., 2006). Specifically, zebrafish treated four days post-fertilization exhibit little hair cell damage while older fish have many more damaged hair cells. This is generally the opposite of mammalian organisms where greater sensitivity to ototoxins is observed during early developmental stages and greater resistance is found in adult specimens (Henley and Rybak, 1995). Further, maturationrelated sensitivity in the zebrafish lateral line has been associated with hair cell type as immature Type I-like hair cells are less susceptible to neomycin but are more strongly affected as they approach maturity (Harris et al., 2003). No studies to date have studied the role of developmental drug sensitivity in fish inner ear hair cells. Therefore, studies of aminoglycosides, and potentially other ototoxic drugs in fish models, should carefully consider how development might affect experimental outcomes.

Transgenic zebrafish expressing fluorescent protein reporters can exhibit impaired hearing. Zebrafish expressing green fluorescent protein (GFP) under the control of the brn3c promoter $\operatorname{Tg}(B r n 3 c$ : GFP) have elevated hearing threshold shifts compared to wild-type controls (Uribe et al., 2013b). This is similar to transgenic mouse models where GFP expression in hair cells is correlated with hearing deficits (Wenzel et al., 2007), while lower levels of GFP in these cells causes no hearing loss (Wang et al., 2013a). It is not certain whether GFP acts as an ototoxin. However, long-term GFP expression in transgenic mice has been linked to aberrant physiology (Huang et al., 2000). Future work will be required to determine whether the expression of fluorescent reporters causes ototoxic effects in zebrafish as well as in mammalian models.

\section{Acoustic Damage}

The hair cells of fishes, like mammals, can be damaged by a variety of sound stimuli. For example, $48 \mathrm{~h}$ of white noise at $180 \mathrm{~dB}$ re: $1 \mu \mathrm{Pa}$ produces hair cell damage in the lagena and saccule of goldfish with saccular damage being particularly localized in the central and caudal regions (Smith et al., 2006). Hair cell loss was also correlated with increased auditory threshold shifts over a range of frequencies $(0.2-2 \mathrm{kHz})$. The goldfish saccule is tonotopically organized, and hair cells in discrete saccular locations are susceptible to stimuli of different frequencies, with low and high frequency sounds damaging hair cells of the caudal and rostral portions of the saccule, respectively (Smith et al., 2011). Similarly, low frequency sound exposure in zebrafish causes distributed hair cell damage in the caudal portion of the saccule (Schuck and Smith, 2009; Sun et al., 2011; Figure 3). Distributed damage patterns in the rostral and caudal portions of the saccule have also been identified 


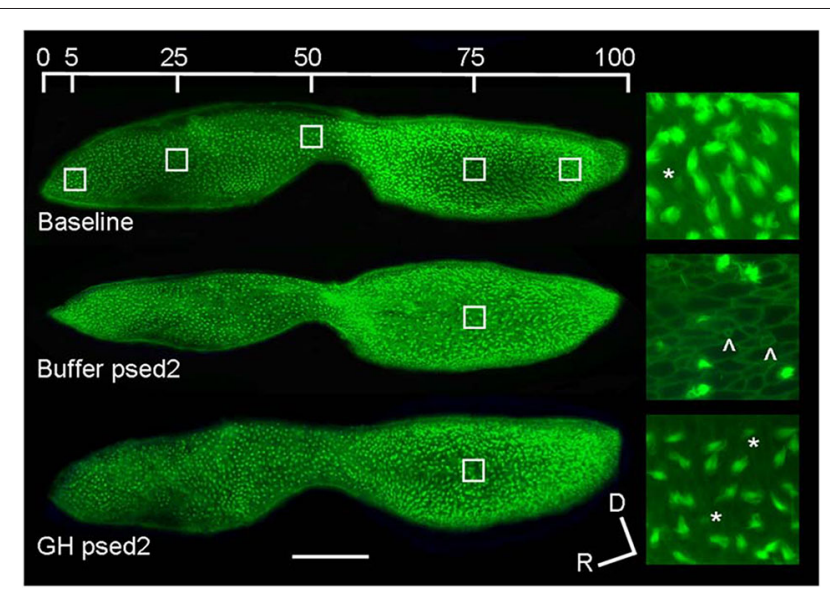

FIGURE 3 | Effect of acoustic exposure on zebrafish saccular hair cell bundle density. Phalloidin-labeled saccular epithelia of baseline, buffer-injected, and $\mathrm{GH}$-injected zebrafish at post-sound exposure day 2 (psed2). The upper image shows the five locations of hair cell counts along the rostral-caudal axis of the saccule. The enlarged images to the right of the saccules are representative 100X images of saccules at $75 \%$ along the rostral-caudal axis. Scale bar, $100 \mu \mathrm{m}, \mathrm{D}=$ dorsal, $\mathrm{R}=$ rostral, * $=$ presumed newly formed hair cell bundles, $\wedge=$ scar formation characteristic of hair cell loss (modified from Sun et al., 2011).

in hybrid striped bass (white bass, Morone chrysops $\times$ striped bass, Morone saxatilis) and tilapia (Oreochromis mossambicus) exposed to pile driver noise (Casper et al., 2013). Similarly, studies conducted in mammalian models show that acoustic damage is often concentrated in different areas of the cochlea with lower frequencies typically damaging mainly outer hair cells and higher frequencies are required to damage inner hair cells (Stockwell et al., 1969; Lim, 1976; Park et al., 2013). As in fish, the mammalian auditory epithelia is tonotopically organized, although, mammalian organization is much more sophisticated (Mann and Kelley, 2011). However, it is unknown whether fish auditory sensory epithelia undergo tonotopic reorganization in response to acoustic damage, which in mammalian models includes changes in electrophysiological response, e.g., threshold response shifts and altered frequency detection, in different regions of the sensory epithelia (Wang et al., 2013b). In general, the cellular damage exhibited by fish and mammals after acoustic over-stimulation is similar. Immediately after zebrafish are sound exposed, hair cell stereociliary numbers are reduced, there are shorter and thinner ciliary bundles, and epithelial lesions where hair cells have been removed (Schuck and Smith, 2009). In mammalian models, after noise exposure, stereocilia are disarrayed or collapsed, and there is scarring where hair cells were located (Stockwell et al., 1969; Lim, 1976; Wang et al., 2002). Thus, fish and mammalian hair cells may be affected similarly by damaging noise stimuli, but there is still limited data on the effects of acoustic trauma on teleost hair cells.

\section{Hair Cell Damage Mechanisms}

Researchers have begun to characterize the mechanisms involved in fish hair cell death and how they relate to mammalian models. The terminal deoxynucleotidyl transferase dUTP nick end labeling (TUNEL) assay shows that noise exposure and ototoxins modulate apoptosis in zebrafish lateral line and inner ear hair cells (Sun et al., 2011; Chang et al., 2013; Hong et al., 2013; Song et al., 2013; Uribe et al., 2013b). Various indicators of apoptosis, e.g., nuclear condensation and fragmentation, can appear rapidly $(30 \mathrm{~min})$ in larval zebrafish neuromasts after cisplatin treatment (Ou et al., 2007). These results are consistent with noise-induced damage and ototoxicity studies conducted using TUNEL in mammalian organisms (Ahn et al., 2005; Chung et al., 2007; Taylor et al., 2008; Fu et al., 2012).

Non-apoptotic mechanisms can also be activated during fish hair cell death. For example, administration of low concentrations of copper causes apoptosis in zebrafish lateral line hair cells but higher concentrations modulate both apoptotic and necrotic mechanisms (Olivari et al., 2008). Non-apoptotic pathways are also activated in mammalian hair cell death. Mice exposed to the aminoglycoside, kanamycin, undergo hair cell death without activation of markers integral to the apoptotic pathway (Jiang et al., 2006). Further, hair cell death in noiseexposed mice can be due to activation of both apoptotic and necrotic pathways (Zheng et al., 2014).

Different pathways in fish hair cells may be targeted by specific ototoxins. Mutational studies show that multiple genes modulate aminoglycoside susceptibility in the larval zebrafish lateral line (Owens et al., 2008). It is likely that these genes function in different pathways, because they provide differential resistance to neomycin. Also, in zebrafish larvae, neomycin and gentamicin ototoxicity follows different time courses suggesting that different cell death mechanisms are targeted (Owens et al., 2009). Screens in larval zebrafish using signal transduction inhibitors targeting the molecules, $\mathrm{Bax}, \mathrm{Bcl} 2$ and $\mathrm{p} 53$, suggest that specific pathways are associated with different otoprotective effects against various aminoglycosides and cisplatin (Coffin et al., 2013a). Studies conducted in mouse models also suggest that different ototoxins can signal through different hair cell death pathways (Jiang et al., 2006; Zheng et al., 2014). However, no studies have yet compared whether specific ototoxic drugs modulate the same apoptotic or necrotic pathways in zebrafish or mammalian models. Recent studies suggest that zebrafish auditory cell apoptosis and necrosis may signal through markers found in rodent models, e.g., Bax, Bcl2, p38, p53 and cytochrome c (Coffin et al., 2013a,b; Shin et al., 2014).

The role of mechanotransducive mechanisms in hair cell death is a potential point of divergence between fish and mammals. A study in the zebrafish lateral line shows that mechanotransduction is required to modulate the ototoxic effects of cisplatin (Thomas et al., 2013). The alkaloid, quinine, an ototoxic mechanotransduction blocker in mammals (Alharazneh et al., 2011), reduces mechanotransduction in the zebrafish lateral line and prevented cisplatin uptake (Thomas et al., 2013). However, work conducted with rodent models indicates that cisplatin uptake in mammals depends upon a variety of membranous transporters, e.g., CTR1, and, therefore, may not require mechanotransduction (Ciarimboli et al., 2010; More et al., 2010; Ding et al., 2011; Ciarimboli, 2012). These findings suggest that cisplatin influx in fish proceeds 
through a different mechanism than in mammals. An additional complicating factor is that hair cell development may intersect with mechanotransduction-modulated ototoxicity and affect the susceptibility of zebrafish to aminoglycosides. As zebrafish hair cells age they become more susceptible to neomycin, and agerelated effects are not dependent upon the onset of functional mechanotransduction (Santos et al., 2006). Much additional work is needed before conclusions can be drawn as to whether zebrafish hair cell death mechanisms are largely equivalent to their mammalian counterparts and if the same pathways are involved in the response to specific ototoxins.

\section{Hair Cell Regeneration}

\section{Cellular Differentiation and Proliferation}

Hair cells can regenerate after damage through transdifferentiation or proliferation of supporting cells (Corwin and Oberholtzer, 1997; Warchol, 2010; Burns and Corwin, 2013; Rubel et al., 2013). Studies conducted using tritium and bromodeoxyuridine (BrdU) labeling show that hair cells in the teleost lateral line and inner ear can undergo continuous proliferation (Jørgensen, 1991; Lanford et al., 1996; Sun et al., 2011). Following acoustic trauma, fish can regenerate hair cells to control levels within one to two weeks, and functional recovery of hearing results (Smith et al., 2006; Faucher et al., 2009). However, regeneration may not proceed, at least in the lateral line, if a certain level of damage is reached. The regenerative potential of neuromasts can be dose-dependent and as damage increases, other cell types from which new hair cells are derived may be permanently destroyed (Hernández et al., 2006).

Several studies have shown that hair cells can regenerate from mitotic and proliferating supporting cells. In the oscar and goldfish inner ear saccule, supporting cells can enter mitotic S-phase and become hair cell precursors (Presson et al., 1995, 1996). In the zebrafish lateral line, hair cells normally undergo programmed cell death during development but are restored from mantle supporting cells at the periphery of the neuromast after S-phase has occurred (Williams and Holder, 2000; Harris et al., 2003). Proliferating supporting cells may either stay in the periphery or migrate inwards and their numbers increase after drug-induced hair cell death. Another zebrafish lateral line study found that most new hair cells are from proliferating supporting cells and that there are two sets of these cells within neuromasts (Ma et al., 2008). One group functions as the progenitors of hair cells and is centrally located. The other is peripheral and of uncertain function. This suggests that there may be functional specializations among neuromast supporting cell populations. These findings are similar to those of transgenic neonatal mouse models where new hairs cells can also proliferate from supporting cells (Shi et al., 2013). In contrast, hair cell regeneration does not occur in adult guinea pigs following damage to both hair and supporting cells suggesting that supporting cells are critical for regeneration (Izumikawa et al., 2008).

Fish hair cells can also regenerate from transdifferentiation of supporting cells. Inflicting high levels of damage to neuromasts causes replacement of hair cells from dividing surrounding supporting cells (Hernández et al., 2007). However, lower levels of damage can cause non-dividing precursor cells to differentiate into hair cells. In developing zebrafish embryos, laser-ablated inner ear hair cells were replaced by supporting cells that underwent transdifferentiation into new hair cells without mitotic proliferation (Millimaki et al., 2010). Transdifferentiation of supporting cells has also been observed in genetically-manipulated mammalian models (Izumikawa et al., 2005).

One potential complication involved in studying cellular differentiation and proliferation in zebrafish is that their lateral line and inner ear hair cells are continually replaced during life (Popper and Hoxter, 1984; Lombarte and Popper, 1994; Higgs et al., 2001, 2003). This could make it difficult to discriminate hair cell regeneration stemming from transdifferentiation as opposed to supporting cell division. However, the application of new technologies, such as laser-scanning confocal microscopy coupled with selective plane illumination microscopy, could facilitate study of these processes by allowing continuous videomicroscopy of different cell types labeled with unique fluorescent markers (Pinto-Teixeira et al., 2013). Thus, this technique could allow investigators to determine which cell types are involved in regeneration and whether new hair cells are produced by transdifferentiation or supporting cell division.

Hair cells in the fish inner ear may exhibit differential spatial patterns of regeneration. In noise-exposed goldfish, hair cell bundle density recovered in the central but not in the caudal portion of the saccule during the study time interval (Smith et al., 2006). After acoustic exposure, hair cells largely regenerated in the caudal region of the saccule, where higher hair cell loss and subsequent mitotic activity was greater than that found in the rostral region (Schuck and Smith, 2009; Figure 4). This was a result of the low frequency sound stimuli used and the tonotopic organization of the teleost saccule (Smith et al., 2011).

\section{Regenerative Mechanisms}

The ability of fish hair cells to regenerate has provoked great interest in identifying the genes and molecular mechanisms that control their differentiation and proliferation. Recent studies have used microarrays and next generation sequencing to identify genes that are activated after hair cell destruction. A microarray performed on zebrafish exposed to noise showed that many gene transcripts were either up- or down-regulated in the inner ear (Schuck et al., 2011; Figure 5). Growth hormone is particularly upregulated while myosin light chain, myosin heavy chain, and major histocompatibility complex I genes were significantly down-regulated. A subsequent study demonstrated that growth hormone can promote regeneration of acoustically- damaged inner ear hair cells in the saccule, utricle and lagena (Sun et al., 2011). Studies in mammalian models suggest that hormones and growth factors can modulate hair cell regeneration. For example, transforming growth factor $\alpha$ and insulin supplemented with epidermal growth factor induced cellular regeneration in mouse vestibular sensory epithelia (Yamashita and Oesterle, 1995). Although, the action of some growth factors, e.g., insulin-like growth factor-1, in mammals 
A

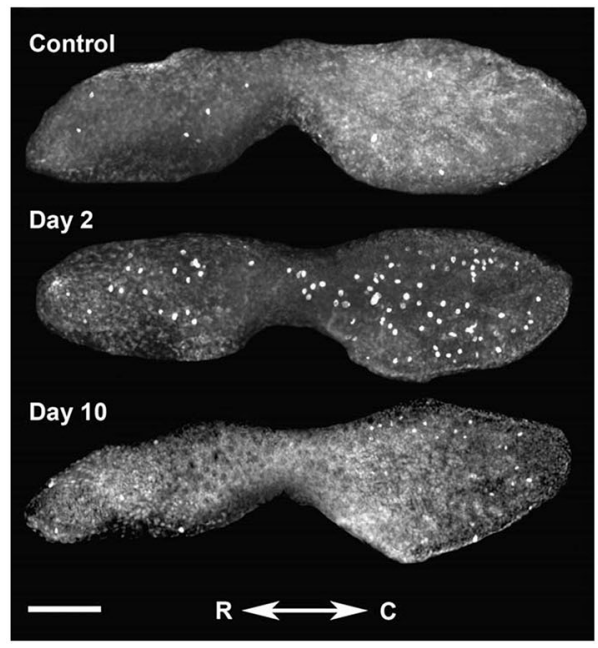

B

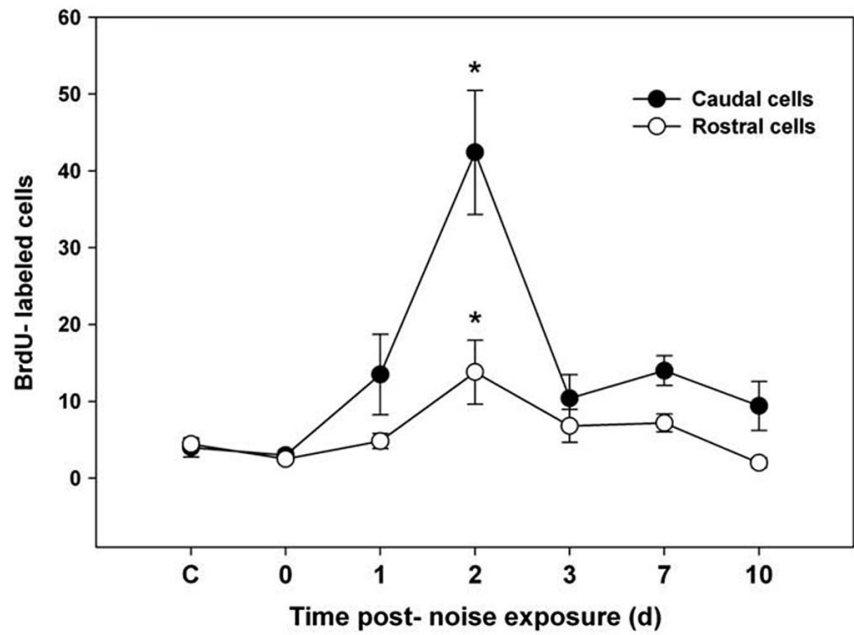

FIGURE 4 | Proliferation follows acoustic trauma to the zebrafish inner ear. (A) BrdU-labeled proliferating cells in a control zebrafish saccule and in saccules dissected for 2 and 10 days post-noise exposure. $\mathrm{C}=$ caudal, $\mathrm{R}=$ rostral; scale bar $=100 \mu \mathrm{m}$. (B) Mean ( \pm SE) BrdU-labeled zebrafish saccular cells as a function of time following sound exposure $\left({ }^{*} p<0.001 ; n=6\right)$. Adapted from Hearing Research, Vol. 253, J.B. Schuck, M.E. Smith, Cell proliferation follows acoustically-induced hair cell bundle loss in the zebrafish saccule, 2009, with permission from Elsevier. may be confined to protective and not regenerative effects (Yamamoto et al., 2014).

Digital gene expression, a form of next generation sequencing, has also been used to identify genes that modulate hair cell regeneration in adult and larval zebrafish (Liang et al., 2012). This showed that the stat $3 / \operatorname{socs} 3$ pathway can modulate hair cell production in the lateral line during development and the adult inner ear during hair cell regeneration, and its expression and activity is associated with supporting cells, differentiating hair cells, and cell division. In mouse models, upstream effectors of Stat3 may be involved in hair cell survival (Hertzano et al., 2004), but no role for Stat3 in hair cell regeneration has yet been reported in mammals.

While microarrays and digital gene expression studies typically use tissue preparations, gene expression can also be studied by collecting samples from individual progenitor cells. For example, lateral line mantle cells can be fluorescentlylabeled, isolated by flow cytometry and then subjected to wholetranscriptome microarray analysis (Steiner et al., 2014). This approach revealed that after hair cell ablation, transcripts coding for transmembrane receptors and cell-adhesion molecules increased. Some of these transcripts were confined to particular mantle cell subsets in specific neuromast regions. Further, transcriptional levels followed a temporal course with maximal changes occurring within $3-5 \mathrm{~h}$ following ablation. Using this methodology, it may possible to further elaborate the mechanistic differences between mammalian and non-mammalian hair cell progenitors.

Chemical screens have also been used to identify compounds that enhance or inhibit hair cell regeneration in the zebrafish lateral line. For example, a chemical screen has been used to identify synthetic glucocorticoid enhancers that promote hair cell regeneration by increasing mitotic activity (Namdaran et al., 2012). This study also identified inhibitors that either reduced hair cell regeneration or prevented supporting cell proliferation, and some of these drugs targeted cell division mechanisms.

Zebrafish studies show that Wnt signaling is involved in hair cell regeneration. In neuromasts, inhibition of $\mathrm{Wnt} / \beta$-catenin signaling reduces proliferation and hair cell differentiation while activation of Wnt increases hair cell numbers and promotes supporting cells to reenter the cell cycle and proliferate (Head et al., 2013; Jacques et al., 2013). Further, Wnt/ $\beta$-catenin activation causes increased hair cell regeneration (Jacques et al., 2013). Neuromast size is also regulated by a negative feedback loop that incorporates Wnt signaling activity (Wada et al., 2013). This promotes surrounding cells to proliferate and is inhibited by Dkk activity from differentiated sensory cells. An analysis of RNA transcripts expressed in the zebrafish lateral line following neomycin-induced damage showed that $\mathrm{Wnt} / \beta$-catenin signaling is down-regulated during earlier time points but becomes up-regulated later (Jiang et al., 2014). This suggests that Wnt is necessary for hair cell proliferation but not immediately after hair cell damage.

Studies of Wnt signaling in zebrafish indicate that the transcription factor Sox2 is involved in hair cell proliferation and transdifferentiation. In one study, new hair cells were derived from proliferating Sox2-positive cells in the prosensory domain (Jacques et al., 2013), and Sox2 is highly expressed in most proliferating neuromast progenitor cells (Hernández et al., 2007). Sox 2 is also required for transdifferentiation of supporting cells (Millimaki et al., 2010). Another important regulator of Wnt/ $\beta$-catenin signaling is ErbB/Neuregulin, which can act upstream to regulate the proliferation of zebrafish lateral line interneuromast cells and the development of intercalary 


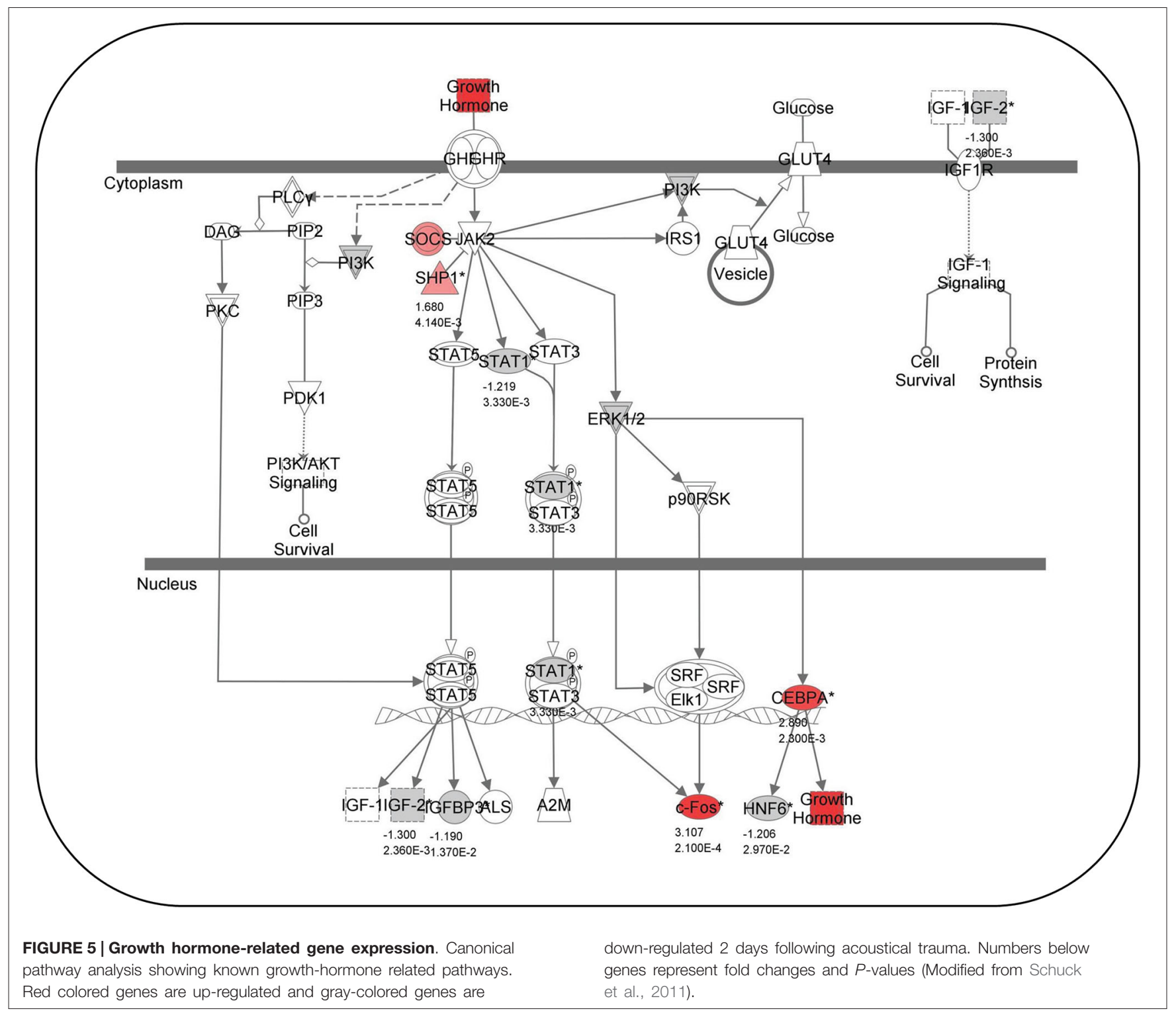

neuromasts (Lush and Piotrowski, 2014b). ErbB signaling is required for the migration of Schwann cells and in the absence of ErbB signaling or Schwann cells, Wnt/ $\beta$-catenin and Fgf (fibroblast growth factor) signaling is increased. Further, Wnt/ $\beta$ catenin signaling is required for interneuromast proliferation, while protoneuromast formation and cellular differentiation requires Fgf signaling (Lush and Piotrowski, 2014b). When ErbB/Neuregulin signaling is reduced, Notch signaling is induced many hours after activation of $\mathrm{Wnt} / \beta$-catenin but before Fgf signaling begins.

The Notch signaling pathway is also a key modulator of hair cell regeneration in the zebrafish lateral line. When supporting cell proliferation and formation of hair cell progenitors is maximal, transcript levels of the Notch pathway components, notch3, deltaA, and atoh1a, increase (Ma et al., 2008). However, inhibiting Notch signaling can also cause hair cell regeneration (Moon et al., 2011). These studies suggest that the Notch pathway modulates regeneration as part of a complex interplay of signaling elements. In the zebrafish mind bomb mutant, DeltaNotch signaling was responsible for controlling supporting cell differentiation into inner ear hair cells (Haddon et al., 1998). A time course analysis of lateral line hair cell regeneration in zebrafish found that Notch signaling is inhibited immediately following hair cell damage (Jiang et al., 2014). The Notch target genes, her4.1, notch3, and sox2, were down-regulated at $1 \mathrm{~h}$, but were up-regulated between 3 and $5 \mathrm{~h}$ after damage. Atohla, a Notch target gene, was up-regulated at $1 \mathrm{~h}$ and deltaD, a target of Atohla, was up-regulated between 3 and $5 \mathrm{~h}$ following damage. The inhibition of Notch, and the up-regulation of atoh1 $a$ and deltaD, suggests that during hair cell regeneration, Notch inhibition needs to be relieved so that supporting cells can leave a quiescent state and begin proliferation. Constitutively expressing Notch can prevent hair cell proliferation from supporting cell progenitors, while eliminating Notch activity 
produces increased numbers of hair cell progenitors and ectopic hair cells (Wibowo et al., 2011). Further, Notch3 activity prevents supporting cells from becoming hair cell progenitors outside of the polar compartments where hair cells regenerate and establish directional symmetry. Thus, when Notch activity is low and Atohla expression is higher within the polar compartment, hair cell progenitor division and immature hair cell formation increases.

Differentiation of hair cell progenitors requires expression of the transcription factor, Atoh1 (Ma and Raible, 2009; Groves et al., 2013). Gain and loss-of-function techniques have been used to characterize the role of Atoh1 in hair cell regeneration. Knockdown of Atohla reduced hair cell formation in the zebrafish inner ear, while rescuing expression restored hair cells (Millimaki et al., 2007). However, excess Atohla expression did not produce ectopic or excess hair cells, as found in rodent models (Zheng and Gao, 2000). Interestingly, adjacent to the lateral line, excess Atohla increased ectopic hair cell placement (Millimaki et al., 2007). These results suggest that Atoh1 signaling may modulate inner ear and lateral line hair cell regeneration differently and may promote different effects in zebrafish and mammalian models. Knockdown of Atoh1 can also reduce zebrafish neuromast development; whereas, rescue or over-expression induces the activity of NeuroD, which is required for hair cell differentiation (Sarrazin et al., 2006). However, mantle and interneuromastic cells are not affected by reduction of Atoh1 protein. Activating Atoh1a signaling in the zebrafish inner ear at different time intervals can cause hair cell formation in distinct spatial regions (Sweet et al., 2011). For example, activation at $18 \mathrm{~h}$ post fertilization (hpf) causes formation of ectopic hair cells in the region normally occupied by the utricular and saccular maculae. At $36 \mathrm{hpf}$, activation caused two discrete and enlarged maculae to appear with an intervening region devoid of hair cells, while at $48 \mathrm{hpf}$, few hair cells develop and no ectopic cells were observed. Although increasing Atoh1 expression in mammalian models can cause hair cell regeneration, these cells typically exhibit aberrant placement and morphology (Sweet et al., 2011). Thus, future research is required to determine whether results obtained with zebrafish models can be applied to mammalian organisms.

Atohla can also regulate hair cell regeneration by modulating ion transport (Go et al., 2010). Specifically, knockdown and inhibition of the plasma membrane calcium transporter ATPase, Atp2b1a (Pmca1), which is controlled by Atoh1a, can affect hair cell regeneration. Knockdown of Atp2b1a blocks calcium export and increases hair cell progenitors. Thus, Atp2b1a might, under control of Atoh1a, affect progenitor cell proliferation and hair cell differentiation via a calcium signaling mechanism. Another ATPase gene, atp1b2b, which regulates $\mathrm{Na}^{+} / \mathrm{K}^{+}$transport, can affect hair cell regeneration (Wang et al., 2008). Knockdown of Eya4, a transcriptional co-activator of Atp1b2b, decreased the number of hair cells in the zebrafish inner ear compartment and lateral line during development. Atp1b2b has a similar spatial and temporal expression as Eya4 and is reduced during Eya4 knockdown. Specific knockdown of Atp1b2b also reduced hair cell numbers in the inner ear compartment and lateral line while over-expression restored the normal phenotype, suggesting that Eya4 may regulate hair cell regeneration by modulating the $\mathrm{Na}^{+} / \mathrm{K}^{+}$-ATPase transporter.

As in zebrafish, Wnt, Notch and related signaling is involved in mammalian hair cell proliferation and transdifferentiation during development. For example, inhibition of Notch signaling causes proliferation of supporting cells in mouse cochlea by acting through the Wnt signaling pathway, however, transdifferentiation was Wnt-independent (Li et al., 2015). In the mouse utricle, inhibition of Notch signaling caused transdifferentiation of supporting cells with little mitotic proliferation (Lin et al., 2011). Transdifferentiation of supporting cells is also promoted by over-expressing Atoh1 in the guinea pig inner ear (Izumikawa et al., 2005). Over-expression in supporting cells of the downstream Wnt signaling molecule, $\beta$-catenin, caused proliferation in some cells and reduced expression of p27, a cell cycle inhibitor (Shi et al., 2013). Similarly, reducing p27 expression in mouse cochlea causes proliferation of hair and supporting cells (Chen and Segil, 1999; Ono et al., 2009). Interestingly, functional assays show no differences in hearing ability between wild type and p27 mutant animals (Walters et al., 2014). In the zebrafish lateral line, when histone deacetylases are inhibited, the numbers of hair and supporting cells decrease, neuromast cellular proliferation is reduced, and p27 mRNA levels increase ( $\mathrm{He}$ et al., 2013). These studies suggest that p27 may regulate cellular proliferation in both zebrafish and mammalian models.

Caspase signaling may also play a role in hair cell regeneration. For example, caspase inhibition reduced hair cell death and supporting cell proliferation in zebrafish peripheral neuromasts (Williams and Holder, 2000). This suggests that caspases could be an integral part of a feedback mechanism that controls supporting cell division and entry into mitosis in response to hair cell death. Caspase activity in zebrafish may function similarly to mammalian models where caspases can modulate apoptosis (Zheng et al., 2014). However, hair cells could be continually renewed from supporting cells in the absence of cell death signaling. A study of hair cell regeneration in the oscar saccule and chicken utricle suggests that supporting cells may not require a cell death signal in the oscar in order to proliferate (Wilkins et al., 1999). In an avian study, caspase inhibition caused reduction of hair cell death and supporting cell proliferation (Matsui et al., 2002) similar to findings in the zebrafish lateral line (Williams and Holder, 2000). Teleosts could have a population of supporting cells that undergo continual renewal without a cell death signal requirement or require such a signal for some or all supporting cells. Alternatively, new hair cells might trigger the death of older cells. Further, as the oscar saccule continues to enlarge during adult life, developmental mechanisms may also be implicated in hair cell regeneration (Wilkins et al., 1999). Future research is needed to characterize the roles played by developmental and intracellular cell death signaling mechanisms in teleosts and their effects on hair cell regeneration.

Other mechanisms have been identified that can modulate teleost hair cell regeneration. The phoenix gene (pho), which is strongly expressed in supporting cells, affects zebrafish hair 
cell proliferation and regeneration (Behra et al., 2009). Pho mutants exhibit normal neuromast and hair cell development. However, when progenitor cells are destroyed in the mutants, supporting cell proliferation and hair cell regeneration is greatly reduced. This suggests that Pho may regulate entry into mitosis. Another mechanism involves histone methylation by lysine specific demethylase 1 (LSD1), which can regulate hair and supporting cell proliferation during development (He et al., 2013). Inhibition of LSD1 reduces the number of hair and supporting cells and suppressed neuromast cellular proliferation. Increased inhibition caused apoptosis within neuromasts. While investigating the origin of new hair cells in the zebrafish lateral line, Lin et al. (2013), found that Rb (retinoblastoma protein) and Raf- 1 kinase were involved in asymmetric cell division in neuromasts. Blocking the interaction between $\mathrm{Rb}$ and $\mathrm{Raf}-1$, and $\mathrm{Rb}$ phosphorylation, prevented hair cell regeneration from supporting cells. In a rat model, inhibition of phosphorylated $\mathrm{Rb}$ promoted proliferation of supporting cells which transdifferentiated into hair cells by activating the sonic hedgehog pathway (Lu et al., 2013).

While most of the research on hair cell regeneration has focused on protein expression at the gene level, microRNAs (miRNAs), which are small, non-coding RNAs that regulate gene expression by translation repression or mRNA destabilization (Friedman et al., 2009), have been shown to play an important role in hair cell development. For example, miRNAs can regulate hair cell proliferation in embryonic zebrafish inner ears (Wienholds et al., 2005; Li et al., 2010). Knockdown of miR-96, -182 and -183 causes a reduction in the numbers of inner ear hair cells. Conversely, over-expressing miR-96 and -182 promotes hair cell production. These miRNAs are also expressed in the mouse inner ear (Weston et al., 2006), and they have been shown to have roles in inner ear development (Sacheli et al., 2009; Soukup, 2009). Further, miR-96 can regulate differentiation of cochlear hair cells (Kuhn et al., 2011). A more in depth review of miRNAs regulated in vertebrate hair cells is provided elsewhere (Smith and Rajadinakaran, 2013).

\section{Future Directions}

\section{Otoprotectants}

One strategy for preventing damage to hair cells is to administer otoprotective drugs that counteract cellular injury from otherwise beneficial drugs (Coffin et al., 2010; Ou et al., 2010; Esterberg et al., 2013). Otoprotectants mainly work by interfering with antibiotic uptake (Hailey et al., 2012; Ou et al., 2012) or inhibiting generation of reactive oxygen species (Le Prell et al., 2007; Wu et al., 2014). The antioxidant epicatechin protects both mammalian and zebrafish hair cells against cisplatin damage and decreases reactive oxygen species generation (Kim et al., 2008). Similarly, Shin et al. (2013), demonstrated that the drug 3-amino-3-(4-fluoro-phenyl)-1H-quinoline-2, 4-dione (KR-22332) provided otoprotective benefits against cisplatin damage in zebrafish and a rat model. The utility of the zebrafish model for discovering potentially otoprotective drugs is well documented. Owens et al. (2008), investigated a library of 10,960 compounds for otoprotective effects in zebrafish larvae and found that two benzothiophene carboximides, PROTO-1 and PROTO-2, acted as otoprotectants. A recent screen in the zebrafish lateral line of 10,000 small molecule inhibitors of cisplatin-mediated hair cell death showed that two compounds, cisplatin hair cell protectant 1 and 2 (CHCP1 and 2), may respectively reduce uptake of a cisplatin analog and affect an intracellular mechanism (Thomas et al., 2015b). Quinoline drugs protective against neomycin and gentamicin mediated damage have also been identified ( $\mathrm{Ou}$ et al., 2012). Vlasits et al. (2012), discovered 10 compounds that prevent several aminoglycosides and cisplatin from damaging hair cells in the larval zebrafish lateral line. Evidently, fish models could provide a very productive framework in the future for screening drug molecules that could offer protection against ototoxic damage, but these drugs still need to be tested in mammalian models.

\section{Cell Cycle Mechanisms}

Studies in zebrafish and mouse models demonstrate that they share key components of several hair cell proliferation pathways, e.g., Wnt, Notch and Rb (Hernández et al., 2007; Liu and Zuo, 2008; Ma et al., 2008; Moon et al., 2011; Head et al., 2013; Jacques et al., 2013; Lin et al., 2013; Mizutari et al., 2013; Wada et al., 2013). Despite this fact, hair cell proliferation does not normally occur in mammals after cells become post-mitotic (Burns and Corwin, 2013). One potential nexus for this divergent cellular behavior could involve regulation of the cell cycle (Liu and Zuo, 2008). Mammalian studies have identified a number of molecules that regulate hair cell entry into mitosis. One of these, the cell cycle inhibitor p27kip, can modulate mammalian hair cell regeneration (Chen and Segil, 1999; Löwenheim et al., 1999; Kanzaki et al., 2006; Ono et al., 2009; Oesterle et al., 2011; Liu et al., 2012; Walters et al., 2014). However, to this date, there is little information available on how cell cycle regulatory mechanisms function in fish hair cell regeneration or what environmental cues modulate them. Studies on this topic, and related signal transduction pathways, would be beneficial not only for our understanding of hair cell regenerative phenomena in fish, but could also have translational applications towards human health.

\section{Reinnervation}

Reinnervation, the reestablishing of functional nervous system connections with target cells, is a necessary concomitant of hair cell regeneration. If neurons are unable to establish appropriate communication with new hair cells, then auditory and vestibular signaling to the brain will not occur. The neuromasts and associated neurons of the embryonic zebrafish lateral line can be stained facilitating the study of neural innervation of the neuromasts using mutant models (Raible and Kruse, 2000). Hair cell polarity in the zebrafish lateral line is important for establishing an appropriate sense of equilibrium (LópezSchier et al., 2004). Mutant fish lacking a planar-polarity protein (Vangl2) have improperly oriented hair cells (LópezSchier and Hudspeth, 2006). Nagiel et al. (2008), and Faucherre et al. (2009), have shown that PLL afferent neurons establish synaptic connections with regenerated hair cells with a particular orientation suggesting that they target a polarity guidance cue. 
Zebrafish unable to transduce mechanical stimuli have afferent neurons that exhibit increased arborization, less stability and more pathfinding errors (Faucherre et al., 2010). Intact lateral line hair cells are not required for neuronal regeneration, but in their absence deviation in pathfinding occurs (Villegas et al., 2012). Also, the synaptic ribbon protein, Ribeye, is required for synaptogenesis and afferent innervation in zebrafish (Sheets et al., 2011). Mo and Nicolson (2011), have investigated the role of $\mathrm{N}$-ethylmaleimide-sensitive factor (Nsf) protein in hair cell synapse maintenance. Afferent neurons retract when Nsf decreases. Reduction of Nsf also caused brainderived neurotrophic factor, BDNF, to accumulate suggesting that $\mathrm{Nsf}$ is required for BDNF release. Injection of BDNF only partially restores afferent synapses indicating that other signaling molecules may be involved in promoting hair cell synaptogenesis. Studies performed in mammalian models show that various stem cell populations can develop the features of spiral ganglion neurons and that their transplantation into the inner ear can restore some auditory function (Diensthuber et al., 2014; Géléoc and Holt, 2014). Another study transplanted spiral ganglion neurons into mice where these neurons had been destroyed and found that the replaced neurons reinnervated and formed new synaptic connections with hair cells (MartinezMonedero et al., 2006). Additional studies in zebrafish will be needed to elucidate the mechanisms that modulate neuronal reinnervation with hair cells and their relatedness to mammalian organisms.

\section{References}

Ahmed, Z. M., Goodyear, R., Riazuddin, S., Lagziel, A., Leagan, P. K., Behra, M., et al. (2006). The tip-link antigen, a protein associated with the transduction complex of sensory hair cells, is Protocadherin-15. J. Neurosci. 26, 7022-7034. doi: 10.1523/jneurosci.1163-06.2006

Ahn, J. H., Kang, H. H., Kim, Y. J., and Chung, J. W. (2005). Anti-apoptotic role of retinoic acid in the inner ear of noise-exposed mice. Biochem. Biophys. Res. Commun. 335, 485-490. doi: 10.1016/j.bbrc.2005.07.114

Alharazneh, A., Luk, L., Huth, M., Monfared, A., Steyger, P. S., Cheng, A. G., et al. (2011). Functional hair cell mechanotransducer channels are required for aminoglycoside ototoxicity. PLoS One 6:e22347. doi: 10.1371/journal.pone. 0022347

Bang, P. I., Sewell, W. F., and Malicki, J. J. (2001). Morphology and cell type heterogeneities of the inner ear epithelia in adult and juvenile zebrafish (Danio rerio). J. Comp. Neurol. 438, 173-190. doi: 10.1002/ cne.1308

Barbazuk, W. B., Korf, I., Kadavi, C., Heyen, J., Tate, S., Wun, E., et al. (2000). The syntenic relationship of the zebrafish and human genomes. Genome Res. 10, 1351-1358. doi: 10.1101/gr.144700

Behra, M., Bradsher, J., Sougrat, R., Gallardo, V., Allende, M. L., and Burgess, S. M. (2009). Phoenix is required for mechanosensory hair cell regeneration in the zebrafish lateral line. PLoS Genet. 5:e1000455. doi: 10.1371/journal.pgen. 1000455

Bever, M. M., and Fekete, D. M. (2002). Atlas of the developing inner ear in zebrafish. Dev. Dyn. 223, 536-543. doi: 10.1002/dvdy.10062

Brignull, H. R., Raible, D. W., and Stone, J. S. (2009). Feathers and fins: nonmammalian models for hair cell regeneration. Brain Res. 1277, 12-23. doi: 10. 1016/j.brainres.2009.02.028

Brown, A. D., Mussen, T. D., Sisneros, J. A., and Coffin, A. B. (2011). Reevaluating the use of aminoglycoside antibiotics in behavioral studies of the lateral line. Hear. Res. 272, 1-4. doi: 10.1016/j.heares.2010.10.014

\section{Conclusion}

Much has been learned in the last decade about hair cell death and regeneration in teleost fishes. Advances derived from studies in zebrafish and other fish species include understanding how ototoxins affect hair cells and discovering new otoprotectants that mitigate ototoxin damage, the role played by cellular proliferation and transdifferentiation during hair cell regeneration, and characterization of the cellular pathways involved in regeneration. Although the zebrafish model has the advantage of higher throughput and easier access to sensory hair cells than mammalian models, because of the different cellular and molecular characteristics of teleost and mammalian auditory cells, data obtained in zebrafish models may not apply to mammalian models. Thus, additional comparative studies involving zebrafish and mammal-based models will be needed to determine whether results obtained in teleosts can be translated into therapeutics to prevent or treat human hearing loss.

\section{Acknowledgments}

This work was supported by an Institutional Development Award (IDeA) from NIH (8 P20 GM103436-12), the Kentucky Science and Engineering Foundation (KSEF-149-502-14-325), and a Western Kentucky University Research and Creative Activities Program Grant to MES.

Buck, L. M., Winter, M. J., Redfern, W. S., and Whitfield, T. T. (2012). Ototoxin induced cellular damage in neuromasts disrupts lateral line function in larval zebrafish. Hear. Res. 284, 67-81. doi: 10.1016/j.heares.2011.12.001

Burns, J. C., Collado, M. S., Oliver, E. R., and Corwin, J. T. (2013). Specializations of intercellular junctions are associated with the presence and absence of hair cell regeneration in ears from six vertebrate classes. J. Comp. Neurol. 521, 1430-1448. doi: 10.1002/cne.23250

Burns, J. C., and Corwin, J. T. (2013). A historical to present-day account of efforts to answer the question: "what puts the brakes on mammalian hair cell regeneration?” Hear. Res. 297, 52-67. doi: 10.1016/j.heares.2013. 01.005

Casper, B. M., Smith, M. E., Halvorsen, M. B., Sun, H., Carlson, T. J., and Popper, A. N. (2013). Effects of exposure to pile driving sounds on fish inner ear tissues. Comp. Biochem. Physiol. A Mol. Integr. Physiol. 166, 352-360. doi: 10.1016/j. cbpa.2013.07.008

Chang, J., Im, G. J., Chae, S. W., Lee, S. H., Kwon, S. Y., Jung, H. H., et al. (2013). Protective role of trimetazidine against neomycin-induced hair cell damage in zebrafish. Clin. Exp. Otorhinolaryngol. 6, 219-225. doi: 10.3342/ceo. 2013.6.4.219

Chang, J. S. Y., Popper, A. N., and Saidel, W. M. (1992). Heterogeneity of sensory hair cells in a fish ear. J. Comp. Neurol. 324, 621-640. doi: 10.1002/cne. 903240413

Chen, P., and Segil, N. (1999). p27 Kip1 links cell proliferation to morphogenesis in the developing organ of Corti. Development 126, 1581-1590.

Chiu, L. L., Cunningham, L. L., Raible, D. W., Rubel, E. W., and Ou, H. C. (2008). Using the zebrafish lateral line to screen for ototoxicity. J. Assoc. Res. Otolaryngol. 9, 178-190. doi: 10.1007/s10162-008-0118-y

Chung, J. W., Ahn, J. H., Kim, J. Y., Lee, H. J., Kang, H. H., Lee, Y. K., et al. (2007). The effect of isoflurane, halothane and pentobarbital on noise-induced hearing loss in mice. Anesth. Analg. 104, 1404-1408. doi: 10.1213/01.ane.0000261508. $24083.6 \mathrm{c}$

Ciarimboli, G. (2012). Membrane transporters as mediators of cisplatin effects and side effects. Scientifica (Cairo) 2012:473829. doi: 10.6064/2012/473829 
Ciarimboli, G., Deuster, D., Knief, A., Sperling, M., Holtkamp, M., Edemir, B., et al. (2010). Organic cation transporter 2 mediates cisplatin-induced oto- and nephrotoxicity and is a target for protective interventions. Am. J. Pathol. 176, 1169-1180. doi: 10.2353/ajpath.2010.090610

Clack, J. A. (2012). Gaining Ground: The Origin and Evolution of Tetrapods. Bloomington, Indiana, USA: Indiana University Press.

Coffin, A., Kelley, M. W., Manley, G. A., and Popper, A. N. (2004). "Evolution of sensory hair cells," in Evolution of the Vertebrate Auditory System, eds G. A. Manley, A. N. Popper, R. R. Fay (New York, NY: Springer Science and Business Media), 55-94.

Coffin, A. B., Ou, H., Owens, K. N., Santos, F., Simon, J. A., Rubel, E. W., et al. (2010). Chemical screening for hair cell loss and protection in the zebrafish lateral line. Zebrafish 7, 3-11. doi: 10.1089/zeb.2009.0639

Coffin, A. B., Rubel, E. W., and Raible, D. W. (2013a). Bax, Bcl2 and p53 differentially regulate neomycin- and gentamicin-induced hair cell death in the zebrafish lateral line. J. Assoc. Res. Otolaryngol. 14, 645-659. doi: 10. 1007/s10162-013-0404-1

Coffin, A. B., Williamson, K. L., Mamiya, A., Raible, D. W., and Rubel, E. W. (2013b). Profiling drug-induced cell death pathways in the zebrafish lateral line. Apoptosis 18, 393-408. doi: 10.1007/s10495-013-0816-8

Coimbra, R. S., Weil, D., Brottier, P., Blanchard, S., Levi, M., Hardelin, J. P., et al. (2002). A subtracted cDNA library from the zebrafish (Danio rerio) embryonic inner ear. Genome Res. 12, 1007-1011. doi: 10.1101/gr.227502

Coombs, S., Braun, C. B., and Donovan, B. (2001). The orienting response of Lake Michigan mottled sculpin is mediated by canal neuromasts. J. Exp. Biol. 204, 337-348.

Corwin, J. T., and Oberholtzer, J. C. (1997). Fish n' chicks: model recipes for haircell regeneration? Neuron 9, 951-954. doi: 10.1016/s0896-6273(00)80386-4

Corwin, J. T., and Warchol, M. E. (1991). Auditory hair cells: structure, function, development and regeneration. Annu. Rev. Neurosci. 14, 301-333. doi: 10. 1146/annurev.neuro.14.1.301

Cruz, S., Shiao, J. C., Liao, B. K., Huang, C. J., and Hwang, P. P. (2009). Plasma membrane calcium ATPase required for semicircular canal formation and otolith growth in the zebrafish inner ear. J. Exp. Biol. 212, 639-647. doi: 10. 1242/jeb.022798

Diensthuber, M., Zecha, V., Wagenblast, J., Arnhold, S., Edge, A. S., and Stöver, T. (2014). Spiral ganglion stem cells can be propagated and differentiated into neurons and glia. Biores. Open Access 3, 88-97. doi: 10.1089/biores.2014.0016

Ding, D., He, J., Allman, B. L., Yu, D., Jiang, H., Seigel, G. M., et al. (2011). Cisplatin ototoxicity in rat cochlear organotypic cultures. Hear. Res. 282, 196-203. doi: 10.1016/j.heares.2011.08.002

Driever, W., Solnica-Krezel, L., Schier, A. F., Neuhauss, S. C., Malicki, J., Stemple, D. L., et al. (1996). A genetic screen for mutations affecting embryogenesis in zebrafish. Development 123, 37-46.

Ernest, S., Rauch, G. J., Haffter, P., Geisler, R., Petit, C., and Nicolson, T. (2000). Marineris defective in myosin VIIA: a zebrafish model for human hereditary deafness. Hum. Mol. Genet. 9, 2189-2196. doi: 10.1093/hmg/9.14.2189

Esterberg, R., Coffin, A. B., Ou, H., Simon, J. A., Raible, D. W., and Rubel, E. W. (2013). Fish in a dish: drug discovery for hearing habilitation. Drug Discov. Today Dis. Models 10, e23-e29. doi: 10.1016/j.ddmod.2012.02.001

Faucher, K., Aas-Hansen, Ø., Damsgård, B., Laukli, E., and Stenklev, N. C. (2009). Damage and functional recovery of the Atlantic cod (Gadus morhua) inner ear hair cells following local injection of gentamicin. Int. J. Audiol. 48, 456-464. doi: 10.1080/14992020902738029

Faucherre, A., Baudoin, J. P., Pujol-Martí, J., and López-Schier, H. (2010). Multispectral four-dimensional imaging reveals that evoked activity modulates peripheral arborization and the selection of plane-polarized targets by sensory neurons. Development 137, 1635-1643. doi: 10.1242/dev.047316

Faucherre, A., Pujol-Martí, J., Kawakami, K., and López-Schier, H. (2009). Afferent neurons of the zebrafish lateral line are strict selectors of hair-cell orientation. PLoS One 4:e4477. doi: 10.1371/journal.pone.0004477

Friedman, R. C., Farh, K. K.-H., Burge, C. B., and Bartel, D. P. (2009). Most mammalian mRNAs are conserved targets of microRNAs. Genome Res. 19, 92-105. doi: 10.1101/gr.082701.108

Fu, Y., Ding, D., Jiang, H., and Salvi, R. (2012). Ouabain-induced cochlear degeneration in rat. Neurotox. Res. 22, 158-169. doi: 10.1007/s12640012-9320-0

Furness, D. N., and Hackney, C. M. (2006). "The structure and composition of the stereociliary bundle of vertebrate hair cells," in Vertebrate Hair Cells, eds R. A.
Eatock, R. R. Fay, A. N. Popper (New York, NY: Springer Science + Business Media, Inc.), 95-153.

Furness, D. N., Hackney, C. M., and Evans, M. G. (2010). Localisation of the mechanotransducer channels in mammalian cochlear hair cells provides clues to their gating. J. Physiol. 588, 765-772. doi: 10.1113/jphysiol.2009.179614

Géléoc, G. S., and Holt, J. R. (2014). Sound strategies for hearing restoration. Science 344:1241062. doi: 10.1126/science.1241062

Ghysen, A., and Dambly-Chaudière, C. (2004). Development of the zebrafish lateral line. Curr. Opin. Neurobiol. 14, 67-73. doi: 10.1016/j.conb.2004.01.012

Giari, L., Dezfuli, B. S., Astolfi, L., and Martini, A. (2012). Ultrastructural effects of cisplatin on the inner ear and lateral line system of zebrafish (Danio rerio) larvae. J. Appl. Toxicol. 32, 293-299. doi: 10.1002/jat.1691

Go, W., Bessarab, D., and Korzh, V. (2010). atp2b1aregulates $\mathrm{Ca}^{2+}$ export during differentiation and regeneration of mechanosensory hair cells in zebrafish. Cell Calcium 48, 302-313. doi: 10.1016/j.ceca.2010.09.012

Goldsmith, J. R., and Jobin, C. (2012). Think small: zebrafish as a model system of human pathology. J. Biomed. Biotechnol. 2012:817341. doi: 10. $1155 / 2012 / 817341$

Groves, A. K. (2010). The challenge of hair cell regeneration. Exp. Biol. Med. (Maywood) 235, 434-446. doi: 10.1258/ebm.2009.009281

Groves, A. K., Zhang, K. D., and Fekete, D. M. (2013). The genetics of hair cell development and regeneration. Annu. Rev. Neurosci. 36, 361-381. doi: 10. 1146/annurev-neuro-062012-170309

Hackney, C. M., and Furness, D. N. (2013). The composition and role of cross links in mechanoelectrical transduction in vertebrate sensory hair cells. J. Cell Sci. 126, 1721-1731. doi: 10.1242/jcs.106120

Haddon, C., Jiang, Y. J., Smithers, L., and Lewis, J. (1998). Delta-Notch signaling and the patterning of sensory cell differentiation in the zebrafish ear: evidence from the mind bomb mutant. Development 125, 4637-4644.

Haddon, C., and Lewis, J. (1996). Early ear development in the embryo of the zebrafish, Danio rerio. J. Comp. Neurol. 365, 113-128. doi: 10.1002/(sici)10969861(19960129)365:1<113::aid-cne9>3.0.co;2-6

Haehnel, M., Taguchi, M., and Liao, J. C. (2012). Heterogeneity and dynamics of lateral line afferent innervation during development in zebrafish (Danio rerio). J. Comp. Neurol. 520, 1376-1386. doi: 10.1002/cne.22798

Hailey, D. W., Roberts, B., Owens, K. N., Stewart, A. K., Linbo, T., Pujol, R., et al. (2012). Loss of Slc4alb chloride/bicarbonate exchanger function protects mechanosensory hair cells from aminoglycoside damage in the zebrafish mutant persephone. PLoS Genet. 8:e1002971. doi: 10.1371/journal. pgen. 1002971

Hammond, K. L., van Eeden, F. J. M., and Whitfield, T. T. (2010). Repression of hedgehog signaling is required for the acquisition of dorsolateral cell fates in the zebrafish otic vesicle. Development 137, 1361-1371. doi: 10.1242/dev.045666

Harris, J. A., Cheng, A. G., Cunningham, L. L., MacDonald, G., Raible, D. W., and Rubel, E. W. (2003). Neomycin-induced hair cell death and rapid regeneration in the lateral line of zebrafish (Danio rerio). J. Assoc. Res. Otolaryngol. 4, 219-234. doi: 10.1007/s10162-002-3022-x

He, Y., Wu, J., Mei, H., Yu, H., Sun, S., Shou, J., et al. (2013). Histone deacetylase activity is required for embryonic posterior lateral line development. Cell Prolif. 47, 91-104. doi: 10.1111/cpr.12081

Head, J. R., Gacioch, L., Pennisi, M., and Meyers, J. R. (2013). Activation of canonical Wnt $/ \beta$-catenin signaling stimulates proliferation in neuromasts in the zebrafish posterior lateral line. Dev. Dyn. 242, 832-846. doi: 10.1002/dvdy. 23973

Henley, C. M., and Rybak, L. P. (1995). Ototoxicity in developing mammals. Brain Res. Brain Res. Rev. 20, 68-90. doi: 10.1016/0165-0173(94)00006-b

Hernández, P. P., Moreno, V., Olivari, F. A., and Allende, M. L. (2006). Sublethal concentrations of waterborne copper are toxic to lateral line neuromasts in zebrafish (Danio rerio). Hear. Res. 213, 1-10. doi: 10.1016/j.heares.2005. 10.015

Hernández, P. P., Olivari, F. A., Sarrazin, A. F., Sandoval, P. C., and Allende, M. L. (2007). Regeneration in zebrafish lateral line neuromasts: expression of the neural progenitor cell marker Sox 2 and proliferation-dependent andindependent mechanisms of hair cell renewal. Dev. Neurobiol. 67, 637-654. doi: 10.1002/dneu.20386

Hertzano, R., Montcouquiol, M., Rashi-Elkeles, S., Elkon, R., Yücel, R., Frankel, W. N., et al. (2004). Transcription profiling of inner ears from Pou4f3 ddl/ddl identifies Gfil as a target of the Pou4f3 deafness gene. Hum. Mol. Genet. 13, 2143-2153. doi: 10.1093/hmg/ddh218 
Higgs, D. M., and Radford, C. A. (2013). The contribution of the lateral line to 'hearing' in fish. J. Exp. Biol. 216, 1484-1490. doi: 10.1242/jeb.078816

Higgs, D. M., Rollo, A. K., Souza, M. J., and Popper, A. N. (2003). Development of form and function in peripheral auditory structures of the zebrafish (Danio rerio). J. Acoust. Soc. Am. 113, 1145-1154. doi: 10.1121/1.15 36185

Higgs, D. M., Souza, M. J., Wilkins, H. R., Presson, J. C., and Popper, A. N. (2001). Age- and size-related changes in the inner ear and hearing ability of the adult zebrafish (Danio rerio). J. Assoc. Res. Otolaryngol. 3, 174-184. doi: 10. $1007 /$ s101620020035

Hirose, Y., Simon, J. A., and Ou, H. C. (2011). Hair cell toxicity in anticancer drugs: evaluating an anti-cancer drug library for independent and synergistic toxic effects on hair cells using the zebrafish lateral line. J. Assoc. Res. Otolaryngol. 12, 719-728. doi: 10.1007/s10162-011-0278-z

Holt, J. R., and Corey, D. P. (2000). Two mechanisms for transducer adaptation in vertebrate hair cells. Proc. Natl. Acad. Sci. U S A 97, 11730-11735. doi: 10. 1073/pnas.97.22.11730

Hong, S. J., Im, G. J., Chang, J., Chae, S. W., Lee, S. H., Kwon, S. Y., et al. (2013). Protective effects of edaravone against cisplatin-induced hair cell damage in zebrafish. Int. J. Pediatr. Otorhinolaryngol. 77, 1025-1031. doi: 10.1016/j.ijporl. 2013.04 .003

Howard, J., and Hudspeth, A. J. (1987). Mechanical relaxation of the hair bundle mediates adaptation in mechanoelectrical transduction by the bullfrog's saccular hair cell. Proc. Natl. Acad. Sci. U S A 84, 3064-3068. doi: 10.1073/pnas. 84.9.3064

Huang, W. Y., Aramburu, J., Douglas, P. S., and Izumo, S. (2000). Transgenic expression of green fluorescence protein can cause dilated cardiomyopathy. Nat. Med. 6, 482-483. doi: 10.1038/74914

Hudspeth, A. J. (1989). How the ear's works work. Nature 341, 397-404. doi: 10. $1038 / 341397 \mathrm{a} 0$

Hudspeth, A. J., Choe, Y., Mehta, A. D., and Martin, P. (2000). Putting ion channels to work: mechanoelectrical transduction, adaptation and amplification by hair cells. Proc. Natl. Acad. Sci. U S A 97, 11765-11772. doi: 10. 1073/pnas.97.22.11765

Inoue, M., Tanimoto, M., and Oda, Y. (2013). The role of ear stone size in hair cell acoustic sensory transduction. Sci. Rep. 3:2114. doi: 10.1038/srep02114

Izumikawa, M., Batts, S. A., Miyazawa, T., Swiderski, D. L., and Raphael, Y. (2008). Response of the flat cochlear epithelium to forced expression of Atoh1. Hear Res. 240, 52-56. doi: 10.1016/j.heares.2008.02.007

Izumikawa, M., Minoda, R., Kawamoto, K., Abrashkin, K. A., Swiderski, D. L., Dolan, D. F., et al. (2005). Auditory hair cell replacement and hearing improvement by Atoh1 gene therapy in deaf mammals. Nat. Med. 11, 271-276. doi: $10.1038 / \mathrm{nm} 1193$

Jacques, B. E., Montgomery, W. H. 4th, Uribe, P. M., Yatteau, A., Asuncion, J. D., Resendiz, G., et al. (2013). The role of $\mathrm{Wnt} / \beta$-catenin signaling in proliferation and regeneration of the developing basilar papilla and lateral line. Dev. Neurobiol. 74, 438-456. doi: 10.1002/dneu.22134

Jiang, L., Romero-Carvajal, A., Haug, J. S., Seidel, C. W., and Piotrowski, T. (2014). Gene-expression analysis of hair cell regeneration in the zebrafish lateral line. Proc. Natl. Acad. Sci. U S A 111, E1383-E1392. doi: 10.1073/pnas.14028 98111

Jiang, H., Sha, S. H., Forge, A., and Schacht, J. (2006). Caspase-independent pathways of hair cell death induced by kanamycin in vivo. Cell Death Differ. 13, 20-30. doi: 10.1038/sj.cdd.4401706

Jørgensen, J. M. (1991). Regeneration of lateral line and inner ear vestibular cells. Ciba Found. Symp. 160, 151-163; discussion 163-170.

Kanzaki, S., Beyer, L. A., Swiderski, D. L., Izumikawa, M., Stöver, T., Kawamoto, K., et al. (2006). p2 $7^{\text {Kip } 1}$ deficiency causes organ of Corti pathology and hearing loss. Hear. Res. 214, 28-36. doi: 10.1016/j.heares.2006.01.014

Kevetter, G. A., and Correia, M. J. (1996). "Vestibular system," in Hearing Loss, eds P. S. Roland, B. F. Marple and W. L. Meyerhoff (New York, NY: Theime Medical Publishers, Inc.), 54-70.

Khorevin, V. I. (2008). The lagena (the third otolithic endorgan in vertebrates). Neurophysiology 40, 142-159. doi: 10.1007/s11062-008-9021-8

Kim, C. H., Kang, S. U., Pyun, J., Lee, M. H., Hwang, H. S., and Lee, H. (2008). Epicatechin protects auditory cells against cisplatin-induced death. Apoptosis 13, 1184-1194. doi: 10.1007/s10495-008-0242-5

Kimmel, C. B. (1989). Genetics and early development of zebrafish. Trends Genet. 5, 283-288. doi: 10.1016/0168-9525(89)90103-0
Kindt, K. S., Finch, G., and Nicolson, T. (2012). Kinocilia mediate mechanosensitivity in developing zebrafish hair cells. Dev. Cell 23, 329-341. doi: 10.1016/j.devcel.2012.05.022

Kuhn, S., Johnson, S. L., Furness, D. N., Chen, J., Ingham, N., Hilton, J. M., et al. (2011). miR-96 regulates the progression of differentiation in mammalian cochlear inner and outer hair cells. Proc. Natl. Acad. Sci. U S A 108, 2355-2360. doi: 10.1073/pnas.1016646108

Kwak, S. J., Vemaraju, S., Moorman, S. J., Zeddies, D., Popper, A. N., and Riley, B. B. (2006). Zebrafish pax 5 regulates development of the utricular macula and vestibular function. Dev. Dyn. 235, 3026-3038. doi: 10.1002/dvdy.20961

Ladich, F., and Schulz-Mirbach, T. (2013). Hearing in cichlid fishes under noise conditions. PLoS One 8:e57588. doi: 10.1371/journal.pone.0057588

Lanford, P. J., Presson, J. C., and Popper, A. N. (1996). Cell proliferation and hair cell addition in the ear of goldfish, Carassius auratus. Hear. Res. 100, 1-9. doi: 10.1016/0378-5955(96)00110-4

Le Prell, C. G., Hughes, L. F., and Miller, J. M. (2007). Free radical scavengers vitamins $\mathrm{A}, \mathrm{C}$, and $\mathrm{E}$ plus magnesium reduce noise trauma. Free Radic. Biol. Med. 42, 1454-1463. doi: 10.1016/j.freeradbiomed.2007.02.008

Leung, K. P., Chen, D., and Chan, K. M. (2014). Understanding copper sensitivity in zebrafish (Danio rerio) through the intracellular localization of copper transporters in a hepatocyte cell-line ZFL and the tissue expression profiles of copper transporters. Metallomics 6, 1057-1067. doi: 10.1039/c3mt00366c

Li, H., Kloosterman, W., and Fekete, D. M. (2010). MicroRNA-183 family members regulate sensorineural fates in the inner ear. J. Neurosci. 30, 3254-3263. doi: 10.1523/JNEUROSCI.4948-09.2010

Li, W., Wu, J., Yang, J., Sun, S., Chai, R., Chen, Z. Y., et al. (2015). Notch inhibition induces mitotically generated hair cells in mammalian cochleae via activating the Wnt pathway. Proc. Natl. Acad. Sci. U S A 112, 166-171. doi: 10.1073/pnas. 1415901112

Liang, J., Wang, D., Renaud, G., Wolfsberg, T. G., Wilson, A. F., and Burgess, S. M. (2012). The stat $3 / \operatorname{socs} 3 a$ pathway is a key regulator of hair cell regeneration in zebrafish stat $3 /$ socs $3 a$ pathway: regulator of hair cell regeneration. J. Neurosci. 32, 10662-10673. doi: 10.1523/JNEUROSCI.5785-10.2012

Liao, J. C. (2006). The role of the lateral line and vision on body kinematics and hydrodynamic preference of rainbow trout in turbulent flow. J. Exp. Biol. 209, 4077-4090. doi: 10.1242/jeb.02487

Lim, D. J. (1976). Ultrastructural cochlear changes following acoustic hyperstimulation and ototoxicity. Ann. Otol. Rhinol. Laryngol. 85, 740-751. doi: $10.1177 / 000348947608500604$

Lin, V., Golub, J. S., Nguyen, T. B., Hume, C. R., Oesterle, E. C., and Stone, J. S. (2011). Inhibition of notch activity promotes nonmitotic regeneration of hair cells in the adult mouse utricles. J. Neurosci. 31, 15329-15339. doi: 10. 1523/JNEUROSCI.2057-11.2011

Lin, Q., Li, W., Chen, Y., Sun, S., and Li, H. (2013). Disrupting Rb-Raf-1 interaction inhibits hair cell regeneration in zebrafish lateral line neuromasts. Neuroreport 24, 190-195. doi: 10.1097/WNR.0b013e32835e3279

Liu, Z., Walters, B. J., Owen, T., Brimble, M. A., Steigelman, K. A., Zhang, L., et al. (2012). Regulation of $\mathrm{p} 27^{K i p 1}$ by Sox 2 maintains quiescence of inner pillar cells in the murine auditory sensory epithelium. J. Neurosci. 32, 10530-10540. doi: 10.1523/JNEUROSCI.0686-12.2012

Liu, Z., and Zuo, J. (2008). Cell cycle regulation in hair cell development and regeneration in the mouse cochlea. Cell Cycle 7, 2129-2133. doi: 10.4161/cc. 7.14.6423

Lombarte, A., and Popper, A. N. (1994). Quantitative analyses of postembryonic hair cell addition in the otolithic end organs of the inner ear of the European hake, Merluccius merluccius (Gadiformes, Teleostei). J. Comp. Neurol. 345, 419-428. doi: 10.1002/cne.903450308

Lombarte, A., Yan, H. Y., Popper, A. N., Chang, J. S., and Platt, C. (1993). Damage and regeneration of hair cell ciliary bundles in a fish ear following treatment with gentamicin. Hear. Res. 64, 166-174. doi: 10.1016/0378-5955(93)90002-i

López-Schier, H., and Hudspeth, A. J. (2006). A two-step mechanism underlies the planar polarization of regenerating sensory hair cells. Proc. Natl. Acad. Sci. U S A 103, 18615-18620. doi: 10.1073/pnas.0608536103

López-Schier, H., Starr, C. J., Kappler, J. A., Kollmar, R., and Hudspeth, A. J. (2004). Directional cell migration establishes the axes of planar polarity in the posterior lateral-line organ of the zebrafish. Dev. Cell. 7, 401-412. doi: 10. 1016/j.devcel.2004.07.018

Löwenheim, H., Furness, D. N., Kil, J., Zinn, C., Gültig, K., Fero, M. L., et al. (1999). Gene disruption of $\mathrm{p} 27^{\mathrm{Kip} 1}$ allows cell proliferation in the postnatal and adult 
organ of Corti. Proc. Natl. Acad. Sci. U S A 96, 4084-4088. doi: 10.1073/pnas. 96.7.4084

Lu, N., Chen, Y., Wang, Z., Chen, G., Lin, Q., Chen, Z. Y., et al. (2013). Sonic hedgehog initiates cochlear hair cell regeneration through downregulation of retinoblastoma protein. Biochem. Biophys. Res. Commun. 430, 700-705. doi: 10. 1016/j.bbrc.2012.11.088

Lush, M. E., and Piotrowski, T. (2014a). Sensory hair cell regeneration in the zebrafish lateral line. Dev. Dyn. 10, 1187-1202. doi: 10.1002/dvdy.24167

Lush, M. E., and Piotrowski, T. (2014b). ErbB expressing Schwann cells control lateral line progenitor cells via non-cell-autonomous regulation of $\mathrm{Wnt} / \beta$ catenin. Elife 3:e01832. doi: 10.7554/eLife.01832

Ma, E. Y., and Raible, D. W. (2009). Signaling pathways regulating zebrafish lateral line development. Curr. Biol. 19, R381-R386. doi: 10.1016/j.cub.2009.03.057

Ma, E. Y., Rubel, E. W., and Raible, D. W. (2008). Notch signaling regulates the extent of hair cell regeneration in the zebrafish lateral line. J. Neurosci. 28, 2261-2273. doi: 10.1523/JNEUROSCI.4372-07.2008

Malicki, J., Schier, A. F., Solnica-Krezel, L., Stemple, D. L., Neuhauss, S. C., Stainier, D. Y., et al. (1996). Mutations affecting development of the zebrafish ear. Development 123, 275-283.

Mann, Z. F., and Kelley, M. W. (2011). Development of tonotopy in the auditory periphery. Hear. Res. 276, 2-15. doi: 10.1016/j.heares.2011.01.011

Martinez-Monedero, R., Corrales, C. E., Cuajungco, M. P., Heller, S., and Edge, A. S. (2006). Reinnervation of hair cells by auditory neurons after selective removal of spiral ganglion neurons. J. Neurobiol. 66, 319-331. doi: 10.1002/neu. 20232

Matsui, J. I., Ogilvie, J. M., and Warchol, M. E. (2002). Inhibition of caspases prevents ototoxic and ongoing hair cell death. J. Neurosci. 22, 1218-1227.

Matsui, J. I., and Ryals, B. M. (2005). Hair cell regeneration: an exciting phenomenon. . but will restoring hearing and balance be possible? J. Rehabil. Res. Dev. 42, 187-198. doi: 10.1682/jrrd.2005.01.0008

McDermott, B. M. Jr., Baucom, J. M., and Hudspeth, A. J. (2007). Analysis and functional evaluation of the hair-cell transcriptome. Proc. Natl. Acad. Sci. U S A 104, 11820-11825. doi: 10.1073/pnas.0704476104

McHenry, M. J., and van Netten, S. M. (2007). The flexural stiffness of superficial neuromasts in the zebrafish (Danio rerio) lateral line. J. Exp. Biol. 210, 4244-4253. doi: 10.1242/jeb.009290

Millimaki, B. B., Sweet, E. M., Dhason, M. S., and Riley, B. B. (2007). Zebrafish atoh1 genes: classic proneural activity in the inner ear and regulation by Fgf and Notch. Development 134, 295-305. doi: 10.1242/dev.02734

Millimaki, B. B., Sweet, E. M., and Riley, B. B. (2010). Sox2 is required for maintenance and regeneration, but not initial development, of hair cells in the zebrafish inner ear. Dev. Biol. 338, 262-269. doi: 10.1016/j.ydbio.2009.12.011

Mizutari, K., Fujioka, M., Hosoya, M., Bramhall, N., Okano, H. J., Okano, H., et al. (2013). Notch inhibition induces cochlear hair cell regeneration and recovery of hearing after acoustic trauma. Neuron 77, 58-69. doi: 10.1016/j.neuron.2012. 10.032

Mo, W., and Nicolson, T. (2011). Both pre- and postsynaptic activity of Nsf prevents degeneration of hair-cell synapses. PLoS One 6:e27146. doi: 10. 1371/journal.pone.0027146

Momin, S. R., Melki, S. J., Obokhare, J. O., Fares, S. A., Semaan, M. T., and Megerian, C. A. (2011). Hearing preservation in Guinea pigs with longstanding endolymphatic hydrops. Otol. Neurotol. 32, 1583-1589. doi: 10. 1097/MAO.0b013e3182382a64

Moon, I. S., So, J. H., Jung, Y. M., Lee, W. S., Kim, E. Y., Choi, J. H., et al. (2011). Fucoidan promotes mechanosensory hair cell regeneration following amino glycoside-induced cell death. Hear. Res. 282, 236-242. doi: 10.1016/j.heares. 2011.07.007

More, S. S., Akil, O., Ianculescu, A. G., Geier, E. G., Lustig, L. R., and Giacomini, K. M. (2010). Role of the copper transporter, CTR1, in platinum-induced ototoxicity. J. Neurosci. 30, 9500-9509. doi: 10.1523/JNEUROSCI.1544-10. 2010

Murakami, S. L., Cunningham, L. L., Werner, L. A., Bauer, E., Pujol, R., Raible, D. W., et al. (2003). Developmental differences in susceptibility to neomycininduced hair cell death in the lateral line neuromasts of zebrafish (Danio rerio). Hear. Res. 186, 47-56. doi: 10.1016/s0378-5955(03)00259-4

Murillo-Cuesta, S., Contreras, J., Cediel, R., and Varela-Nieto, I. (2010). Comparison of different aminoglycoside antibiotic treatments to refine ototoxicity studies in adult mice. Lab. Anim. 44, 124-131. doi: 10.1258/la.2009. 009046
Nagiel, A., Andor-Ardó, D., and Hudspeth, A. J. (2008). Specificity of afferent synapses onto plane-polarized hair cells in the posterior lateral line of the zebrafish. J. Neurosci. 28, 8442-8453. doi: 10.1523/JNEUROSCI.242508.2008

Namdaran, P., Reinhart, K. E., Owens, K. N., Raible, D. W., and Rubel, E. W. (2012). Identification of modulators of hair cell regeneration in the zebrafish lateral line. J. Neurosci. 32, 3516-3528. doi: 10.1523/JNEUROSCI.3905-11.2012

Nicolson, T. (2005). The genetics of hearing and balance in zebrafish. Annu. Rev. Genet. 39, 9-22. doi: 10.1146/annurev.genet.39.073003.105049

Nicolson, T., Rüsch, A., Friedrich, R. W., Granato, M., Ruppersberg, J. P., and Nüsslein-Volhard, C. (1998). Genetic analysis of vertebrate sensory hair cell mechanosensation: the zebrafish circler mutants. Neuron 20, 271-283. doi: 10. 1016/s0896-6273(00)80455-9

Oesterle, E. C., Chien, W. M., Campbell, S., Nellimarla, P., and Fero, M. L. (2011). $\mathrm{p} 27^{\mathrm{Kip} 1}$ is required to maintain proliferative quiescence in the adult cochlea and pituitary. Cell Cycle 10, 1237-1248. doi: 10.4161/cc.10.8.15301

Oesterle, E. C., and Stone, J. S. (2008). "Hair cell regeneration: mechanisms guiding cellular proliferation and differentiation," in Hair Cell Regeneration, Repair and Protection, eds R. J. Salvi, A. N. Popper and R. R. Fay (New York: Springer), 141-198.

Olivari, F. A., Hernández, P. P., and Allende, M. L. (2008). Acute copper exposure induces oxidative stress and cell death in lateral line hair cells of zebrafish larvae. Brain Res. 1244, 1-12. doi: 10.1016/j.brainres.2008.09.050

Olt, J., Johnson, S. L., and Marcotti, W. (2014). In vivo and in vitro biophysical properties of hair cells from the lateral line and inner ear of developing and adult zebrafish. J. Physiol. 592, 2041-2058. doi: 10.1113/jphysiol.2013.265108

Ono, K., Nakagawa, T., Kojima, K., Matsumoto, M., Kawauchi, T., Hoshino, M., et al. (2009). Silencing p27 reverses post-mitotic state of supporting cells in neonatal mouse cochleae. Mol. Cell. Neurosci. 42, 391-398. doi: 10.1016/j.mcn. 2009.08.011

Ou, H. C., Raible, D. W., and Rubel, E. W. (2007). Cisplatin-induced hair cell loss in zebrafish (Danio rerio) lateral line. Hear. Res. 233, 46-53. doi: 10.1016/j. heares.2007.07.003

Ou, H. C., Santos, F., Raible, D. W., Simon, J. A., and Rubel, E. W. (2010). Drug screening for hearing loss: using the zebrafish lateral line to screen for drugs that prevent and cause hearing loss. Drug Discov. Today 15, 265-271. doi: 10. 1016/j.drudis.2010.01.001

Ou, H., Simon, J. A., Rubel, E. W., and Raible, D. W. (2012). Screening for chemicals that affect hair cell death and survival in the zebrafish lateral line. Hear. Res. 288, 58-66. doi: 10.1016/j.heares.2012.01.009

Owens, K. N., Coffin, A. B., Hong, L. S., Bennett, K. O., Rubel, E. W., and Raible, D. W. (2009). Response of mechanosensory hair cells of the zebrafish lateral line to aminoglycosides reveals distinct cell death pathways. Hear. Res. 253, 32-41. doi: 10.1016/j.heares.2009.03.001

Owens, K. N., Santos, F., Roberts, B., Linbo, T., Coffin, A. B., Knisely, A. J., et al. (2008). Identification of genetic and chemical modulators of zebrafish mechanosensory hair cell death. PLoS Genet. 4:e1000020. doi: 10.1371/journal. pgen. 1000020

Pan, B., Géléoc, G. S., Asai, Y., Horwitz, G. C., Kurima, K., Ishikawa, K., et al. (2013). TMC1 and TMC2 are components of the mechanotransduction channel in hair cells of the mammalian inner ear. Neuron 79, 504-515. doi: 10. 1016/j.neuron.2013.06.019

Park, S. N., Back, S. A., Park, K. H., Seo, J. H., Noh, H. I., Akil, O., et al. (2013). Comparison of functional and morphologic characteristics of mice models of noise-induced hearing loss. Auris Nasus Larynx 40, 11-17. doi: 10.1016/j.anl. 2011.11.008

Pickles, J. O., Brix, J., Gleich, O., Köppl, C., Manley, G. A., Osborne, M. P., et al. (1988). "The fine structure and organization of tip links on hair cell stereovilli," in Basic Issues in Hearing, eds H. Duifhuis, J. W. Horst and H. P. Wit (London: Academic Press), 56-63.

Pinto-Teixeira, F., Muzzopappa, M., Swoger, J., Mineo, A., Sharpe, J., and LópezSchier, H. (2013). Intravital imaging of hair-cell development and regeneration in the zebrafish. Front. Neuroanat. 7:33. doi: 10.3389/fnana.2013.00033

Popper, A. N. (1983). "Organization of the inner ear and processing of acoustic information," in Fish Neurobiology and Behavior, eds R. G. Northcutt and R. E. Davis (Ann Arbor, MI: University of Michigan Press), 125-178.

Popper, A. N. (2000). Hair cell heterogeneity and ultrasonic hearing: recent advances in understanding fish hearing. Philos. Trans. R. Soc. Lond. B Biol. Sci. 355, 1277-1280. doi: 10.1098/rstb.2000.0683 
Popper, A. N., Fay, R. R., Platt, C., and Sand, O. (2003). "Sound detection mechanisms and capabilities of teleost fishes," in Sensory Processing in Aquatic Environments, eds S. P. Collin and N. J. Marshall (New York, NY: SpringerVerlag New York, Inc.), 3-38.

Popper, A. N., and Hoxter, B. (1984). Growth of a fish ear: 1. Quantitative analysis of hair cell and ganglion cell proliferation. Hear. Res. 15, 133-142. doi: 10. 1016/0378-5955(84)90044-3

Popper, A. N., and Hoxter, B. (1990). Growth of a fish ear. II. Locations of newly proliferated sensory hair cells in the saccular epithelium of Astronotus ocellatus. Hear. Res. 45, 33-40. doi: 10.1016/0378-5955(90)90180-w

Presson, J. C., Lanford, P. J., and Popper, A. N. (1996). Hair cell precursors are ultrastructurally indistinguishable from mature support cells in the ear of a postembryonic fish. Hear. Res. 100, 10-20. doi: 10.1016/0378-5955(96)00109-8

Presson, J. C., Smith, T., and Mentz, L. (1995). Proliferating hair cell precursors in the ear of a postembryonic fish are replaced after elimination by cytosine arabinoside. J. Neurobiol. 26, 579-584. doi: 10.1002/neu.480260410

Qi, W., Ding, D., and Salvi, R. J. (2008). Cytotoxic effects of dimethyl sulphoxide (DMSO) on cochlear organotypic cultures. Hear. Res. 236, 52-60. doi: 10. 1016/j.heares.2007.12.002

Raible, D. W., and Kruse, G. J. (2000). Organization of the lateral line system in embryonic zebrafish. J. Comp. Neurol. 421, 189-198. doi: 10.1002/(sici)10969861(20000529)421:2<189::aid-cne5>3.3.co;2-b

Ramcharitar, J. U., and Brack, C. L. (2010). Physiological dimensions of ototoxic responses in a model fish species. J. Clin. Neurosci. 17, 103-106. doi: 10.1016/j. jocn.2009.08.003

Rubel, E. W., Furrer, S. A., and Stone, J. S. (2013). A brief history of hair cell regeneration research and speculations on the future. Hear. Res. 297, 42-51. doi: 10.1016/j.heares.2012.12.014

Sacheli, R., Nguyen, L., Borgs, L., Vandenbosch, R., Bodson, M., Lefebvre, P., et al. (2009). Expression patterns of miR-96, miR-182 and miR-183 in the development inner ear. Gene Expr. Patterns 9, 364-370. doi: 10.1016/j.gep.2009. 01.003

Santos, F., MacDonald, G., Rubel, E. W., and Raible, D. W. (2006). Lateral line hair cell maturation is a determinant of aminoglycoside susceptibility in zebrafish (Danio rerio). Hear. Res. 213, 25-33. doi: 10.1016/j.heares.2005.12.009

Sarrazin, A. F., Villablanca, E. J., Nuñez, V. A., Sandoval, P. C., Ghysen, A., and Allende, M. L. (2006). Proneural gene requirement for hair cell differentiation in the zebrafish lateral line. Dev. Biol. 295, 534-545. doi: 10.1016/j.ydbio.2006. 03.037

Schibler, A., and Malicki, J. (2007). A screen for genetic defects of the zebrafish ear. Mech. Dev. 124, 592-604. doi: 10.1016/j.mod.2007.04.005

Schuck, J. B., and Smith, M. E. (2009). Cell proliferation follows acousticallyinduced hair cell bundle loss in the zebrafish saccule. Hear. Res. 253, 67-76. doi: 10.1016/j.heares.2009.03.008

Schuck, J. B., Sun, H., Penberthy, W. T., Cooper, N. G., Li, X., and Smith, M. E. (2011). Transcriptomic analysis of the zebrafish inner ear points to growth hormone mediated regeneration following acoustic trauma. BMC Neurosci. 12:88. doi: 10.1186/1471-2202-12-88

Sheets, L., Trapani, J. G., Mo, W., Obholzer, N., and Nicolson, T. (2011). Ribeye is required for presynaptic $\mathrm{Ca}_{V} 1.3 \mathrm{a}$ channel localization and afferent innervation of sensory hair cells. Development 138, 1309-1319. doi: 10.1242/dev.059451

Shi, F., Hu, L., and Edge, A. S. (2013). Generation of hair cells in neonatal mice by $\beta$-catenin overexpression in Lgr5-positive cochlear progenitors. Proc. Natl. Acad. Sci. U S A 110, 13851-13856. doi: 10.1073/pnas.1219952110

Shin, Y. S., Hwang, H. S., Kang, S. U., Chang, J. W., Oh, Y. T., and Kim, C. H. (2014). Inhibition of p38 mitogen-activated protein kinase ameliorates radiation-induced ototoxicity in zebrafish and cochlea-derived cell lines. Neurotoxicology 40, 111-122. doi: 10.1016/j.neuro.2013.12.006

Shin, Y. S., Song, S. J., Kang, S. U., Hwang, H. S., Choi, J. W., Lee, B. H., et al. (2013). A novel synthetic compound, 3-amino-3-(4-fluoro-phenyl)-1H-quinoline-2,4dione, inhibits cisplatin-induced hearing loss by the suppression of reactive oxygen species: In vitro and in vivo study. Neuroscience 232, 1-12. doi: 10. 1016/j.neuroscience.2012.12.008

Siemens, J., Lillo, C., Dumont, R. A., Reynolds, A., Williams, D. S., Gillespie, P. G., et al. (2004). Cadherin 23 is a component of the tip link in hair-cell stereocilia. Nature 428, 950-955. doi: 10.1038/nature02483

Smith, M. E., Coffin, A. B., Miller, D. L., and Popper, A. N. (2006). Anatomical and functional recovery of the goldfish (Carassius auratus) ear following noise exposure. J. Exp. Biol. 209, 4193-4202. doi: 10.1242/jeb.02490
Smith, M. E., and Rajadinakaran, G. (2013). The transcriptomics to proteomics of hair cell regeneration: looking for a hair cell in a haystack. Microarrays (Basel) 2, 186-207. doi: 10.3390/microarrays 2030186

Smith, M. E., Schuck, J. B., Gilley, R. R., and Rogers, B. D. (2011). Structural and functional effects of acoustic exposure in goldfish: evidence for tonotopy in the teleost saccule. BMC Neurosci. 12:19. doi: 10.1186/1471-2202-12-19

Song, J. J., Chang, J., Choi, J., Im, G. J., Chae, S. W., Lee, S. H., et al. (2013). Protective role of NecroX-5 against neomycin-induced hair cell damage in zebrafish. Arch. Toxicol. 88, 435-441. doi: 10.1007/s00204-013-1124-3

Song, J., Yan, H. Y., and Popper, A. N. (1995). Damage and recovery of hair cells in fish canal (but not superficial) neuromasts after gentamicin exposure. Hear. Res. 91, 63-71. doi: 10.1016/0378-5955(95)00170-0

Soukup, G. A. (2009). Little but loud: small RNAs have a resounding affect on ear development. Brain Res. 1277, 104-114. doi: 10.1016/j.brainres.2009.02.027

Steiner, A. B., Kim, T., Cabot, V., and Hudspeth, A. J. (2014). Dynamic gene expression by putative hair-cell progenitors during regeneration in the zebrafish lateral line. Proc. Natl. Acad. Sci. U S A 111, E1393-E1401. doi: 10. 1073/pnas.1318692111

Stockwell, C. W., Ades, H. W., and Engström, H. (1969). Patterns of hair cell damage after intense auditory stimulation. Ann. Otol. Rhinol. Laryngol. 78, 1144-1168. doi: 10.1177/000348946907800602

Strassmaier, M., and Gillespie, P. G. (2002). The hair cell's transduction channel. Curr. Opin. Neurobiol. 12, 380-386. doi: 10.1016/S0959-4388(02)00344-6

Suli, A., Watson, G. M., Rubel, E. W., and Raible, D. W. (2012). Rheotaxis in larval zebrafish is mediated by lateral line mechanosensory hair cells. PLoS One 7:e29727. doi: 10.1371/journal.pone.0029727

Sun, H., Lin, C. H., and Smith, M. E. (2011). Growth hormone promotes hair cell regeneration in the zebrafish (Danio rerio) inner ear following acoustic trauma. PLoS One 6:e28372. doi: 10.1371/journal.pone.0028372

Sweet, E. M., Vemaraju, S., and Riley, B. B. (2011). Sox2 and Fgf interact with Atoh1 to promote sensory competence throughout the zebrafish inner ear. Dev. Biol. 358, 113-121. doi: 10.1016/j.ydbio.2011.07.019

Szabo, T. M., McCormick, C. A., and Faber, D. S. (2007). Otolith endorgan input to the Mauthner neuron in the goldfish. J. Comp. Neurol. 505, 511-525. doi: 10. $1002 /$ cne.21499

Tanimoto, M., Ota, Y., Horikawa, K., and Oda, Y. (2009). Auditory input to CNS is acquired coincidentally with development of inner ear after formation of functional afferent pathway in zebrafish. J. Neurosci. 29, 2762-2767. doi: 10. 1523/JNEUROSCI.5530-08.2009

Tanimoto, M., Ota, Y., Inoue, M., and Oda, Y. (2011). Origin of inner ear hair cells: morphological and functional differentiation from ciliary cells into hair cells in zebrafish inner ear. J. Neurosci. 31, 3784-3794. doi: 10.1523/jneurosci.555410.2011

Taylor, R. R., Nevill, G., and Forge, A. (2008). Rapid hair cell loss: a mouse model for cochlear lesions. J. Assoc. Res. Otolaryngol. 9, 44-64. doi: 10.1007/s10162007-0105-8

Thomas, E. D., Cruz, I. A., Hailey, D. W., and Raible, D. W. (2015b). There and back again: development and regeneration of the zebrafish lateral line system. Wiley Interdiscip. Rev. Dev. Biol. 4, 1-16. doi: 10.1002/wdev.160

Thomas, A. J., Hailey, D. W., Stawicki, T. M., Wu, P., Coffin, A. B., Rubel, E. W., et al. (2013). Functional mechanotransduction is required for cisplatin-induced hair cell death in the zebrafish lateral line. J. Neurosci. 33, 4405-4414. doi: 10. 1523/jneurosci.3940-12.2013

Thomas, A. J., Wu, P., Raible, D. W., Rubel, E. W., Simon, J. A., and $\mathrm{Ou}$, H. C. (2015a). Identification of small molecule inhibitors of Cisplatininduced hair cell death: results of a 10,000 compound screen in the zebrafish lateral line. Otol. Neurotol. 36, 519-525. doi: 10.1097/mao.000000000 0000487

Ton, C., and Parng, C. (2005). The use of zebrafish for assessing ototoxic and otoprotective agents. Hear. Res. 208, 79-88. doi: 10.1016/j.heares.2005. 05.005

Uribe, P. M., Mueller, M. A., Gleichman, J. S., Kramer, M. D., Wang, Q., SibrianVazquez, M., et al. (2013a). Dimethyl sulfoxide (DMSO) exacerbates cisplatininduced sensory hair cell death in zebrafish (Danio rerio). PLoS One 8:e55359. doi: 10.1371/journal.pone.0055359

Uribe, P. M., Sun, H., Wang, K., Asuncion, J. D., Wang, Q., Chen, C. W., et al. (2013b). Aminoglycoside-induced hair cell death of inner ear organs causes functional deficits in adult zebrafish (Danio rerio). PLoS One 8:e58755. doi: 10. 1371/journal.pone.0058755 
Van Trump, W. J., Coombs, S., Duncan, K., and McHenry, M. J. (2010). Gentamicin is ototoxic to all hair cells in the fish lateral line system. Hear. Res. 261, 42-50. doi: 10.1016/j.heares.2010.01.001

Van Trump, W. J., and McHenry, M. J. (2008). The morphology and mechanical sensitivity of lateral line receptors in zebrafish larvae (Danio rerio). J. Exp. Biol. 211, 2105-2115. doi: 10.1242/jeb.016204

Vater, M., Meng, J., and Fox, R. C. (2004). "Hearing organ evolution and specialization: early and later mammals," in Evolution of the Vertebrate Auditory System, eds G. A. Manley, A. N. Popper and R. R. Fay (New York: Springer-Verlag), 256-288.

Villegas, R., Martin, S. M., O’Donnell, K. C., Carrillo, S. A., Sagasti, A., and Allende, M. L. (2012). Dynamics of degeneration and regeneration in developing zebrafish peripheral axons reveals a requirement for extrinsic cell types. Neural Dev. 7:19. doi: 10.1186/1749-8104-7-19

Vlasits, A. L., Simon, J. A., Raible, D. W., Rubel, E. W., and Owens, K. N. (2012). Screen of FDA-approved drug library reveals compounds that protect hair cells from aminoglycosides and cisplatin. Hear. Res. 294, 153-165. doi: 10.1016/j. heares.2012.08.002

Wada, H., Ghysen, A., Asakawa, K., Abe, G., Ishitani, T., and Kawakami, K. (2013). Wnt/Dkk negative feedback regulates sensory organ size in zebrafish. Curr. Biol. 23, 1559-1565. doi: 10.1016/j.cub.2013.06.035

Walters, B. J., Liu, Z., Crabtree, M., Coak, E., Cox, B. C., and Zuo, J. (2014). Auditory hair cell-specific deletion of $\mathrm{p}^{2} 7^{\text {Kip } 1}$ in postnatal mice promotes cellautonomous generation of new hair cells and normal hearing. J. Neurosci. 34, 15751-15763. doi: 10.1523/jneurosci.3200-14.2014

Wang, Y., Hirose, K., and Liberman, M. C. (2002). Dynamics of noise-induced cellular injury and repair in the mouse cochlea. J. Assoc. Res. Otolaryngol. 3, 248-268. doi: 10.1007/s101620020028

Wang, L., Sewell, W. F., Kim, S. D., Shin, J. T., MacRae, C. A., Zon, L. I., et al. (2008). Eya4 regulation of $\mathrm{Na}^{+} / \mathrm{K}^{+}$-ATPase is required for sensory system development in zebrafish. Development 135, 3425-3434. doi: 10.1242/dev. 012237

Wang, Y., Sun, Y., Chang, Q., Ahmad, S., Zhou, B., Kim, Y., et al. (2013a). Early postnatal virus inoculation into the scala media achieved extensive expression of exogenous green fluorescent protein in the inner ear and preserved auditory brainstem response thresholds. J. Gene Med. 15, 123-133. doi: 10.1002/ jgm.2701

Wang, F., Zuo, L., Hong, B., Han, D., Range, E. M., Zhao, L., et al. (2013b). Tonotopic reorganization and spontaneous firing in inferior colliculus during both short and long recovery periods after noise overexposure. J. Biomed. Sci. 20:91. doi: 10.1186/1423-0127-20-91

Warchol, M. E. (2010). Cellular mechanisms of aminoglycoside ototoxicity. Curr. Opin. Otolaryngol. Head Neck Surg. 18, 454-458. doi: 10.1097/moo. 0b013e32833e05ec

Wenzel, G. I., Xia, A., Funk, E., Evans, M. B., Palmer, D. J., Ng, P., et al. (2007). Helper-dependent adenovirus-mediated gene transfer into the adult mouse cochlea. Otol. Neurotol. 28, 1100-1108. doi: 10.1097/mao.0b013e31 $8158973 \mathrm{f}$

Weston, M. D., Pierce, M. L., Rocha-Sanchez, S., Beisel, K. W., and Soukup, G. A. (2006). MicroRNA gene expression in the mouse inner ear. Brain Res. 1111, 95-104. doi: 10.1016/j.brainres.2006.07.006
Wibowo, I., Pinto-Teixeira, F., Satou, C., Higashijima, S., and López-Schier, H. (2011). Compartmentalized Notch signaling sustains epithelial mirror symmetry. Development 138, 1143-1152. doi: 10.1242/dev.060566

Wienholds, E., Kloosterman, W. P., Miska, E., Alvarez-Saavedra, E., Berezikov, E., de Bruijn, E., et al. (2005). MicroRNA expression in zebrafish embryonic development. Science 309, 310-311. doi: 10.1126/science.1114519

Wilkins, H. R., Presson, J. C., and Popper, A. N. (1999). Proliferation of vertebrate inner ear supporting cells. J. Neurobiol. 39, 527-535. doi: 10.1002/(sici)10974695(19990615)39:4<527::aid-neu6>3.0.co;2-k

Williams, J. A., and Holder, N. (2000). Cell turnover in neuromasts of zebrafish larvae. Hear. Res. 143, 171-181. doi: 10.1016/s0378-5955(00)00039-3

Wu, C. Y., Lee, H. J., Liu, C. F., Korivi, M., Chen, H. H., and Chan, M. H. (2014). Protective role of L-ascorbic acid, N-acetylcysteine and apocynin on neomycin-induced hair cell loss in Zebrafish. J. Appl. Toxicol. 35, 273-279. doi: 10.1002/jat.3043

Yamamoto, N., Nakagawa, T., and Ito, J. (2014). Application of insulin-like growth factor-1 in the treatment of inner ear disorders. Front. Pharmacol. 5:208. doi: 10.3389/fphar.2014.00208

Yamashita, H., and Oesterle, E. C. (1995). Induction of cell proliferation in mammalian inner-ear sensory epithelia by transforming growth factor $\alpha$ and epidermal growth factor. Proc. Natl. Acad. Sci. U S A 92, 3152-3155. doi: 10. 1073/pnas.92.8.3152

Yan, H. Y., Saidel, W. M., Chang, J. S., Presson, J. C., and Popper, A. N. (1991). Sensory hair cells of a fish ear: evidence of multiple types based on ototoxicity sensitivity. Proc. Biol. Sci. 245, 133-138. doi: 10.1098/rspb.1991.0099

Zhai, F., Liu, J. P., Dai, C. F., Wang, Q., and Steyger, P. S. (2010). Evidencebased modification of intratympanic gentamicin injections in patients with intractable vertigo. Otol. Neurotol. 31, 642-648. doi: 10.1097/mao. 0b013e3181dbb30e

Zhao, B., Wu, Z., Grillet, N., Yan, L., Xiong, W., Harkins-Perry, S., et al. (2014). TMIE is an essential component of the mechanotransduction machinery of cochlear hair cells. Neuron 84, 954-967. doi: 10.1016/j.neuron.2014.10.041

Zheng, H. W., Chen, J., and Sha, S. H. (2014). Receptor-interacting protein kinases modulate noise-induced sensory hair cell death. Cell Death Dis. 5:e1262. doi: 10 1038/cddis.2014.177

Zheng, J. L., and Gao, W.-Q. (2000). Overexpression of Math1 induces robust production of extra hair cells in postnatal rat inner ears. Nat. Neurosci. 3, 580-586. doi: 10.1038/75753

Zon, L. I. (1999). Zebrafish: a new model for human disease. Genome Res. 9, 99-100. doi: 10.1101/gr.9.2.99

Conflict of Interest Statement: The authors declare that the research was conducted in the absence of any commercial or financial relationships that could be construed as a potential conflict of interest.

Copyright (C) 2015 Monroe, Rajadinakaran and Smith. This is an open-access article distributed under the terms of the Creative Commons Attribution License (CC BY). The use, distribution and reproduction in other forums is permitted, provided the original author(s) or licensor are credited and that the original publication in this journal is cited, in accordance with accepted academic practice. No use, distribution or reproduction is permitted which does not comply with these terms. 